\title{
1 Biological Flora of Central Europe: Impatiens glandulifera Royle
}

3 Kenny Helsen ${ }^{1,2}$, Martin Diekmann ${ }^{3}$, Guillaume Decocq ${ }^{4}$, Karen De Pauw ${ }^{5}$, Sanne Govaert ${ }^{5}$,

4 Bente Jessen Graae ${ }^{6}$, Jenny Hagenblad ${ }^{7}$, Jaan Liira ${ }^{8}$, Anna Orczewska ${ }^{9}$, Pieter Sanczuk ${ }^{5}$, $5 \quad$ Koenraad Van Meerbeek ${ }^{10} \&$ Pieter De Frenne ${ }^{5}$.

6

$7 \quad{ }^{1}$ Plant Conservation and Population Biology, KU Leuven, Arenbergpark 31, BE-3001 Leuven, 8 Belgium. ${ }^{2}$ Institute of Ecology and Evolutionary Biology, National Taiwan University, No. 9 237, Zhoushan Road, Da'an District, Taipei 106, Taiwan. ${ }^{3}$ Vegetation Ecology and 10 Conservation Biology, Faculty of Biology/Chemistry (FB 02), Institute of Ecology, University 11 of Bremen, Leobener Strasse 5, 28359 Bremen, Germany. ${ }^{4}$ Research Unit "Ecologie et 12 Dynamique des Systèmes Anthropisés”, EDYSAN, UMR 7058 CNRS, Université de Picardie 13 Jules Verne, 1 rue des Louvels, FR-80037, Amiens cedex, France. ${ }^{5}$ Forest \& Nature Lab, Ghent 14 University, Geraardsbergsesteenweg 267, BE-9090 Melle-Gontrode, Belgium. ${ }^{6}$ Department of 15 Biology, Norwegian University of Science and Technology, NTNU, NO-7491, Trondheim, 16 Norway. ${ }^{7}$ Department of Physics, Chemistry and Biology, Linköping University, SE-581 83 17 Linköping, Sweden. ${ }^{8}$ Institute of Ecology and Earth Sciences, University of Tartu, Lai 40, 18 Tartu EE51005, Estonia. ${ }^{9}$ Institute of Biology, Biotechnology and Environmental Protection, 19 Faculty of Natural Sciences, University of Silesia, Bankowa 9, 40-007 Katowice, Poland.

$20{ }^{10}$ Division Forest, Nature and Landscape, Department of Earth and Environmental Sciences, 21 KU Leuven, Celestijnenlaan 200E, 3001 Heverlee, Belgium.

$22 \quad$ Corresponding author: kenny.helsen@kuleuven.be

24 Keywords 
25 Annual plant; Himalayan balsam; invasion impact; invasive alien species; management; spread

\section{Abstract}

This paper presents all current knowledge on the biology of the invasive therophyte Impatiens glandulifera Royle (Himalayan Balsam), and covers aspects of taxonomy, morphology, distribution, habitat requirements, ecology, life cycle, genetics, history of invasive spread, ecological impact and management. Although a few review papers have been published on this species in previous decades, a great deal of insights have been gained in the last three decades, owing to the species' notorious reputation as one of the most problematic invasive species in Europe. This study consequently focusses on this novel information, with a particular focus on information from Central Europe.

\section{Introduction}

The therophyte Impatiens glandulifera Royle (Himalayan Balsam) is considered one of the most problematic invasive plant species in Europe. Consequently, much research has been performed on this species in the last decades. The last reviews on this species, however, data back to the last two decades (Beerling and Perrins, 1993; Clements et al., 2008; Cockel and Tanner, 2011). Consequently, this study aims at synthesizing the latest research on this species, combining information on the species' general biology and its invasive spread, impact and management across its full range. More specifically, we firstly update the information provided in Beerling and Perrins (1993) on I. glandulifera's taxonomy, morphology, distribution, habitat

47 requirements, ecology, life cycle, biotic interactions and genetic data. Secondly, we combine this information with an overview of the insights gained on the species' invasive behaviour, 
ecosystem impact and management; research fields that have received particular research attention during the last decades.

\section{Taxonomy and morphology}

\subsection{Taxonomy}

Impatiens glandulifera Royle is a balsam species of the genus Impatiens, within the

Balsaminaceae family. The family includes only two genera: Impatiens L. (c. 900 species) and Hydrocera Blume (1 species). The family Balsaminaceae was formerly treated as a separate order, i.e. the Balsaminales, or classified as a member of the order Geraniales. Recent molecular phylogenetic analyses revealed that Balsaminaceae is part of the Ericales (which currently comprises 22 families in the APG IV system (Stevens, 2001)), and sits as sister group to all other Balsaminoid Ericales (Marcgraviaceae, Pellicieraceae and Tetrameristaceae families) (Anderberg et al., 2002; Geuten et al., 2004). Impatiens species are mostly native to tropical mountain forests of the old world. Only one species (I. noli-tangere L.) is native to Europe. I. glandulifera is part of a basal clade within the Balsaminaceae, containing species that are mainly distributed in the Himalaya and regions of Eurasia with a temperate climate (Janssens et al., 2006). The family includes many species of ornamental interest, with Impatiens walleriana Hook.f. and I. hawkeri W. Bull being among the most sold ornamentals worldwide (Grey-Wilson, 1983). Some of these ornamentals have become highly invasive, such as $I$. capensis Meerb., I. parviflora D.C., I. balfouri Hook.f and I. glandulifera in Europe; I. walleriana in the tropics and I. niamniamensis Gilg in New Zealand (Adamowski, 2008). The Plant List currently mentions 5 resolved synonyms of I. glandulifera Royle, including I. macrochila Lindl., I. roylei Walpers, Balsamina glandulifera (Royle) Ser., B. macrochila (Lind1.) Ser. and B. roylei (Walp.) Ser. (The Plant List, 2013). Special attention 
synonym of I. taprobanica Hiern, native to Sri Lanka. Three infraspecific taxa (i.e. forms) of

I. glandulifera have furthermore been distinguished according to the colour of flowers: albida

(Hegi) B. Boivin: white flowers; pallidiflora (Hook. f.) Weath.: light pink flowers; and glandulifera Vahl: dark pink flowers (Ebel and Mikhailova, 2016; Missouri Botanical Garden, 2008).

Common names include Himalayan balsam, Indian balsam, Policeman's helmet,

Gnome's hatstand, Bobby tops, Kiss-me-on-the-mountain, and Ornamental jewelweed

(English); Drüsiges Springkraut, Indisches Springkraut, Drüsenspringkraut, Drüsentragendes

Springkraut, Riesenspringkraut (German); Netýkavka žláznatá (Czech); Netýkavka žliazkatá

(Slovak); Žlezava nedotika (Slovene); Nedirak (Croatian); Bíbor nebáncsvirág (Hungarian);

Niecierpek gruczołowaty, Niecierpek himalajski, Niecierpek Roylego (Polish).

Hybrids between I. glandulifera and other Impatiens species have not been reported to

date. However, natural pollen transfer between I. glandulifera and I. balfourii by pollinators has been observed in France and artificial pollination between the two species results in seed production, although these seeds germinated only occasionally (Ugoletti et al., 2013).

89

\subsection{Morphology}

I. glandulifera has an erect, solitary, tall, thick stem, green to reddish in colour, usually simple or sometimes branching, usually 5-50 mm in diameter (Fig. 1A) (Beerling and Perrins, 1993). Plants can usually reach 1-2 (2.5) meter in height, and even $3 \mathrm{~m}$ plants have occasionally been reported, making it the tallest annual species in the UK and likely also in the rest of Europe (Andrews et al., 2005; Chittka and Schürkens, 2001; Grime et al., 1988; Willis and Hulme, 2004). The whole plant is glabrous (Balogh, 2008). The stems are hollow and thickened at the nodes, with strengthening elements (a ring of lignified vascular tissue containing lignin and 
99 (Beerling and Perrins, 1993; Ennos et al., 1993; Spatz et al., 1990). How tall I. glandulifera

100 individuals grow depends on many abiotic and biotic factors, including soil nutrients and

101 moisture (Grime et al., 1988), temperature (growing degree hours) (Helsen et al., 2017),

102 latitude (length of the growing season, photoperiod) (Helsen et al., 2020a; Kollmann and

103 Bañuelos, 2004), and the level of irradiance (see parts 5.6, 5.9 and 6.3). In its native range the

104 species was found to have a smaller plant height than in Europe in some (Gruntman et al., 2020;

105 Tanner et al., 2008), but not all studies (Tanner et al., 2014b).

106 I. glandulifera has two contrasting root forms: 2-4 cylindrical primary or seminal roots

107 of 2-3 mm diameter, with an anatomy typical of dicot roots, and numerous $(146 \pm 35)$ tapered,

108 fleshy adventitious roots, of an average length of $15-20 \mathrm{~cm}$, showing a stem-like anatomy, with

109 similar peripheral strengthening elements. The adventitious roots emerge from the hollow,

110 wide stem base. Roots grow downwards, and form the shape of an inverted cone with top

111 diameter reaching c. $6 \mathrm{~cm}$, and length c. $8 \mathrm{~cm}$. The adventitious roots grow in irregular

112 concentric circles (rows), emerging progressively higher up the stem, therefore the large, upper

113 ones are the youngest. Numerous, narrow lateral roots emerge from the upper parts of the main

114 roots, which are responsible for resource acquisition (Ennos et al., 1993). The rooting depth

115 ranges from 10 to $50 \mathrm{~cm}$ (Fitter and Peat, 1994). Plants can also form adventitious roots on the

116 stem when wounded, allowing re-rooting of broken or bent stems (Fig. 1D) (Beerling and

117 Perrins, 1993; McClatchie, 1917).

118 Leaves are set opposite or arranged in whorls of 2-5 (Tanner, 2011), although more

119 whorls develop in shaded conditions (Kostrakiewicz-Gierałt, 2015). The leaves are lanceolate

120 to elliptic-ovate, serrulate to sharply toothed, with $18-50$ teeth on each side, cuneate, glandular

121 and shortly decurrent at base and acuminate at their apex (Fig. 1B) (Beerling and Perrins, 1993).

122 Purple headed glands located on their base are extrafloral nectaries, which contain high levels

123 of antimicrobial naphthoquinones (Fig. 1B) (Balogh, 2008; Block et al., 2019) (see part 5.10). 
124 On average, leaves are 5-18 cm long and 2.5-7 cm wide, and have - not so common for terrestrial dicots - an equal amount of stomata on the adaxial (upper) and abaxial (downward)

126 side (Beerling and Perrins, 1993) or higher on the abaxial side $\left(277 \mathrm{~mm}^{-2}\right)$ than the adaxial side $127\left(137 \mathrm{~mm}^{-2}\right)$ (Fitter and Peat, 1994) (Fig. 2). The average leaf area is $119.10 \mathrm{~cm}^{2}$ with a mean 128 mass of $312 \mathrm{mg}$ and average leaf dry matter content (LDMC) of $137 \mathrm{mg} \mathrm{g}^{-1}$, resulting in an 129 average specific leaf area (SLA) of $38.3 \mathrm{~mm}^{2} \mathrm{mg}^{-1}$ (Kleyer et al., 2008). The average leaf area seems to gradually decrease, and SLA gradually increase, with increasing temperature

131 (decreasing latitude) in Europe (Helsen et al., 2020b, 2018b) (Table 1). More specifically, SLA 132 has been found to vary between 25 and $40 \mathrm{~mm}^{2} \mathrm{mg}^{-1}$ in situ, and can even reach $100 \mathrm{~mm}^{2} \mathrm{mg}^{-}$

$133{ }^{1}$ under low-light greenhouse conditions (Helsen et al., 2018b; Gruntman et al., 2020). Smaller 134 leaves have been reported to develop in well-illuminated sites (Maule et al., 2000) and in dry habitats (Grime et al., 1988), and large leaf area variation within populations seems to occur in both dry and very wet locations (Helsen et al., 2017) (see part 5.9).

138 flowers that are 25-40 mm long (Fig. 1A) (Beerling and Perrins, 1993). The petals are variable

139 in colour, usually lilac, pink or purple and occasionally white (Beerling and Perrins, 1993); the 140 latter being an anthocyanin-free form (Ebel and Mikhailova, 2016). Flowers are zygomorphic 141 and of pungent, sweet scent (Fitter and Peat, 1994; Tanner, 2011). The five stamens are fused 142 by their anthers and form a brush covering the stigma, with both suspended downward from 143 the roof of the lower sepal (Kostrakiewicz-Gierałt, 2015; Vervoort et al., 2011). A lower, 144 posterior sepal forms a sac (12-20 $\mathrm{mm}$ long and 9-17 $\mathrm{mm}$ wide) abruptly ending in an incurved spur, 2-7 mm long. Two lateral sepals are oblique cordate, and small (Balogh, 2008; Beerling and Perrins, 1993; eFloras, 2020). There are five, broad petals, the upper (dorsal) is strongly

147 arched, and the lateral ones are joined in pairs, forming the lower lip - the landing site of 
148 pollinators, while the upper petal forms a characteristic hood above the stamens (Fig. 1C)

149 (Balogh, 2008; Beerling and Perrins, 1993).

150 The fruit is a fleshy capsule, $1.5-3.5(5.0) \mathrm{cm}$ long and $0.4-1.5 \mathrm{~cm}$ wide, lanceolate,

151 distinctively widening to the apex, slightly five-angled (Fig. 1A\&C) (Balogh, 2008). Seeds are

152 oval-globose and discolour from pale grey-brown to black at maturity. The seeds are 3-4 (7)

$153 \mathrm{~mm}$ long, 2-4.8 mm wide and 1.5-2 mm thick (Balogh, 2008; Fitter and Peat, 1994;

154 Helmisaari, 2010) and have a rugose, ruminate seed coat type (Maciejewska-Rutkowska and

155 Janczak, 2016). Part 5.4 contains more details on fruit and seed morphology.

156

157 4. Distribution and habitat requirements

158 4.1. Distribution and invasion history

159 I. glandulifera is reported as native to three countries in the foothills of the western Himalaya,

160 i.e. northeast Pakistan, northwest India (Jammu and Kashmir, Himachal Pradesh, Uttarakhand)

161 and likely western Nepal (Fig. 3A) (Beerling and Perrins, 1993; CABI, 2020; Fitter and Peat,

162 1994; Stace, 2019). In this relatively small range (estimated at approximately $800 \mathrm{~km}$ in length

163 and $50 \mathrm{~km}$ in width, Tanner et al. (2008)), the species grows in the elevational belt with a

164 temperate climate between 2000 and $4000 \mathrm{~m}$ above sea level (a.s.1.) (Beerling and Perrins,

165 1993; Hagenblad et al., 2015).

166 The first reported introduction of I. glandulifera into Europe was from Kashmir into

167 England in 1839, where it was introduced as an ornamental plant to the Botanic Gardens at

168 Kew (Beerling and Perrins, 1993). Within the following decade the species was also introduced 169 across the European continent (e.g. in Sweden (1842), Austria (1845) and Czech Republic

170 (1846)) (Čuda et al., 2020). In the late 1800s, roughly 40 years after these initial introductions,

171 the species became naturalised, further spreading across the European continent (Britten, 1900;

172 Čuda et al., 2020; Pyšek and Prach, 1995), and most likely also to other continents ( $\breve{C} u d a$ et 
al., 2020; Mills et al., 1993; Nagy and Korpelainen, 2015). Population genetic analyses have indicated that I. glandulifera has been introduced to the UK at least 3 times from different locations in its native range (Ellison et al., 2020; Kurose et al., 2020) (see part 6.2). The species now occurs in at least 32 countries across Europe, from the British Isles in the west to Poland, Belarus and Russia in the east, and from northern Italy, northern Spain, in the south to northern Scandinavia (Fig. 3B) (CABI, 2020; GBIF Secretariat, 2019). The species is largely absent from truly Mediterranean vegetation types. The species has recently also spread in the Balkans and the Caucasus (Fayvush and Tamanyan, 2011; GBIF Secretariat, 2019; Komzha and Popov, 1990; Pacanoski and Saliji, 2014), and is naturalized in Russia

182 (European part, far East and, recently, the Altai Republic), China (Hunan), Japan, New 183 Zealand, Argentina and both western and eastern Canada and USA (Fig. 3A) (Artemov and Zykova, 2019; CABI, 2020; Čuda et al., 2020; EPPO, 2020; GBIF Secretariat, 2019; Vinogradova et al., 2020). In the USA, the species was first reported from Norwich (Connecticut) in 1883 and in Canada from Ottawa in 1901, with initial introductions possibly 187 through ship's ballast from Europe (Clements et al., 2008; Mills et al., 1993; Tabak and Von 188 Wettberg, 2008).

Since the 1960's, I. glandulifera has strongly increased in abundance across most

190 European countries (Čuda et al., 2020; Zając et al., 2011) (e.g. Fig. 4). Interestingly, increased 191 abundances seem independent from the time of introduction, with a shorter lag phase in 192 locations of later introduction (Pyšek and Prach, 1995). The species has furthermore strongly 193 advanced its northern range limits in the last decades, with a c. $1400 \mathrm{~km}$ expansion along the entire Atlantic coast of Norway and a c. $300 \mathrm{~km}$ shift along the Baltic coast of Sweden (Fig. 3B\&C). Remarkably, this poleward expansion was almost perfectly predicted by a species distribution model in 1993, under a $1.5{ }^{\circ} \mathrm{C}$ warming scenario (Beerling, 1993). This model

197 included only the minimum winter temperature and the heat sum (growing degree days) as 
predictor variables, of which just the latter seemingly controlled the northern distribution limit.

199 Winter temperatures nonetheless limited the species' germination, growth and fecundity in a sowing experiment along an elevational gradient in northeast England, suggesting some importance of minimum temperatures on its European distribution (Willis and Hulme, 2002).

202 Currently, the northernmost observation is a population northwest of Alta in northern Norway

$203\left(70.2^{\circ} \mathrm{N}\right)($ GBIF Secretariat, 2019). The spread is thus likely to continue with global warming toward higher latitudes and altitudes. It has, on the other hand, been suggested that the southern distribution boundary might move northwards in response to increasing summer drought (Beerling, 1993).

The climatic amplitude across the species' vast European range of $2,926,000 \mathrm{~km}^{2}$ is wide: the mean temperature range is $8.4{ }^{\circ} \mathrm{C}$ for the whole year and $13.9{ }^{\circ} \mathrm{C}$ for the growing season (April - September) for the period 1970-2000 (Vangansbeke et al., 2020). The cold mean annual temperature limit is $5.5^{\circ} \mathrm{C}(5$ percentile of occupied grid cells) and the warm limit is $11.6{ }^{\circ} \mathrm{C}$ (95 percentile). The mean precipitation across the European range is $725 \mathrm{~mm}$, with

212 a 5 and 95 percentile of 520 and $1278 \mathrm{~mm}$, respectively (Vangansbeke et al., 2020). Across the

$21310 \mathrm{~km}^{2}$-hectads occupied by the species in Britain, the January mean temperature was $3.7^{\circ} \mathrm{C}$, the July mean temperature $15.1{ }^{\circ} \mathrm{C}$, and the mean precipitation $957 \mathrm{~mm}$ over the period 1961 1990 (Hill et al., 2004).

Unlike in its native range, I. glandulifera mainly occurs in lowland locations in Europe,

217 with observations near sea level and only up to $1200 \mathrm{~m}$ in the Austrian Alps (Drescher and 218 Prots, 2000) and $800 \mathrm{~m}$ in the Polish Carpathians (Zając et al., 2011; Zając and Zając, 2015).

219 The mean elevation of occurrence of the species across 2954 resurveyed vegetation plots in temperate European forests, for example, was $259 \mathrm{~m}$ a.s.l., with a minimum of $19 \mathrm{~m}$, and a maximum of $330 \mathrm{~m}$ a.s.l. (Zellweger et al., 2020). 


\subsection{Habitat}

In Europe, I. glandulifera is most typical for river valleys and its associated riparian habitats.

It grows on riverbanks, in reeds, in and along alder and willow thickets, in fens and, increasingly, also in moist deciduous or coniferous forests, as well as along forest paths (Beerling and Perrins, 1993; Čuda et al., 2020; Mossberg and Stenberg, 2018). In the latter habitats, the species often co-occurs with its congeners I. parviflora and I. noli-tangere, which, under most conditions, are competitively inferior to I. glandulifera (Čuda et al., 2015; Skálová et al., 2013). I. glandulifera occasionally colonizes roadsides in several European countries (Follak et al., 2018), and can also occur in (sub-montane) meadows, field borders and fallow, and anthropogenically disturbed land (Kiełtyk and Delimat, 2019; Kostrakiewicz-Gierałt, 2015; Prowse, 2001). In Canada, the species occurs along riverbanks, marshes, bogs, ditches and roadsides, and thus appears to occupy similar habitats as in Europe (Clements et al., 2008). With its affinity to riparian zones, I. glandulifera's habitat preference in its invaded range differs from that in the Himalayas, where it is most frequent in high altitude (> $2000 \mathrm{~m}$ a.s.1.) meadows, ditches between fields, along roads and in fringes and openings of deciduous and coniferous forests (Cockel and Tanner, 2011; Čuda et al., 2020; Drescher and Prots, 2000).

I. glandulifera prefers moist to wet, base- and nutrient-rich soils across its European

range, as reflected in its (central European) Ellenberg species indicator values for soil moisture F (8), soil acidity R (7) and soil nutrients N (7) (Ellenberg and Leuschner, 2010) and similar

242 Swedish ecological soil indicator values for moisture (7), $\mathrm{pH}$ (6) and nitrogen availability (8)

243 (Tyler et al., 2021). The latter source also provides an indicator value of 5 for soil phosphorus availability, on a scale from 1 to 5 (Tyler et al., 2021). However, the species also tolerates drier, more acidic and less fertile conditions and a broad range of soil types and textures, growing on

246 fine or coarse alluvial soils, shingle, free-draining mineral soils and peat (Beerling and Perrins, 247 1993) (see part 4.4). 


\subsection{Communities}

In Central Europe, I. glandulifera mainly occurs in the following communities (Drescher and Prots, 1996; Klotz et al., 2002; Tokarska-Guzik et al., 2012) (the nomenclature follows Mucina et al. (2016)):

253 - Hydrophilous, semi-natural, tall herb fringe communities of riverbanks and other water 254 bodies of both lowlands and uplands (Convolvuletalia sepium and Adenostylion alliariae)

- $\quad$ Reed swamps of mesotrophic and eutrophic, slowly flowing or stagnating freshwater bodies (Phragmitetalia)

257 - Sedge-bed marsh vegetation (Magnocaricetalia)

258 - Willow scrub and open forests of riparian habitats (Salicetalia purpureae, Salicion albae)

259 - Mesotrophic, regularly flooded alder carr (Alnetalia glutinosae)

260 I. glandulifera is also regularly found in anthropogenic, disturbed habitats assigned to:

261 - Ruderal semi-natural fringe vegetation (Galio-Alliarietalia)

262 - Semi-natural fringe vegetation of rivers and other waters (Convolvuletalia sepium)

263 - Perennial ruderal, xerophylous vegetation (Artemisietea vulgaris)

264 - Tall herb semi-natural vegetation of forest edges and clearings (Galeopsio-Senecionetalia sylvatici, Epilobion angustifolii)

In Poland the species has been encountered in nine different Natura 2000 habitat types,

267 largely comprising the communities described above (Adamowski et al., 2018). A distinct $I$. glandulifera dominated association termed Impatienti-Calystegietum has been recognized (Dajdok et al., 2003), and the species was also found in sub-montane fresh meadows and road verges of the Molinio-Arrhenatheretea class (Kiełtyk and Delimat, 2019). In the UK, four main

271 communities with I. glandulifera were distinguished: riverine, partly inundated communities, 272 Phragmites-Urtica fens, mesotrophic grasslands, and different types of woodland, including 
273 Alnus glutinosa-Urtica dioica woodland, both the typical and Sambucus nigra subtypes (i.e.

274 NVC classification type W6a and W6d) (Beerling and Perrins, 1993; Fitter and Peat, 1994).

275 For Sweden, the following broad vegetation types containing I. glandulifera are distinguished:

276 Tall herb/sedge/reed meadows; Eutrophic water \& shores; Ruderal communities; Hedgerows,

277 thickets, wood-margins and groves; and Alnus glutinosa swamps (Tyler et al., 2021).

278 The species most frequently co-occurring with I. glandulifera in riparian habitats are

279 relatively constant across Europe and consist mostly of perennial, tall forbs and grasses (Table

280 2) (e.g. Beerling and Perrins, 1993; Dajdok et al., 2003; Diekmann et al., 2016; Drescher and

281 Prots, 1996; Helsen et al., 2018b; Kiełtyk and Delimat, 2019; Prowse, 2001). Species of other

282 life forms, such as vines and woody species, are less often associated. Among the frequent

283 and/or abundant associates of I. glandulifera in Central Europe are also Carduus crispus,

284 Glyceria maxima, Lamium maculatum, Myosoton aquaticum and Symphytum officinale (Hejda

285 and Pyšek, 2006; Helmisaari, 2010; Oberdorfer, 1983). In the UK, I. glandulifera additionally

286 occurs quite frequently with Lamium album (Hulme and Bremner, 2006).

287 Woody species most often co-occurring with I. glandulifera are Alnus sp., Fraxinus

288 excelsior and Salix sp. (Kostrakiewicz-Gierałt and Zajac, 2014; Vinogradova et al., 2020).

289 Especially at disturbed fertile sites, I. glandulifera may co-occur with other neophytes such as

290 Solidago gigantea, I. parviflora, Aster sp., Fallopia sp. and Echinocystis lobata, the latter

291 occurring solely in Eastern Europe (Drescher and Prots, 1996). Such communities were

292 described as a separate Impatienti-Solidaginetum for the hilly and (sub-) montane regions in

293 Switzerland (Moor, 1958) and in the Czech Republic (Kopecký, 1967; Lhotska and Kopecký, 294 1966).

295 The most frequent companion of I. glandulifera in Europe is Urtica dioica (Table 2).

296 The two species compete strongly: while the perennial Urtica starts to grow in early spring and

297 has a fast growth rate, I. glandulifera germinates later, but is capable of withstanding the shade 
and root competition and, with an even higher growth rate, overtops $U$. dioica by mid-summer, before flowering. Although the dominant aspect of I. glandulifera suggests that the species has a strong negative effect on species diversity, it appears to fill the niche that otherwise $U$. dioica would have taken up (Gruntman et al., 2014; Koenies and Glavac, 1979; Tickner et al., 2001). In its native range, I. glandulifera often occurs in tall herb communities in the scrublands and pastures of the Himalayan cedar (Cedrus deodara) mixed forest zone (Balogh, 2008). Here the species can be considerably smaller than in Europe, and forms small populations of 30-60 individuals, mixed in with other native vegetation (Tanner et al., 2008, but see Tanner et al., 2014b). Co-occurring species include representatives of the Asteraceae,

Cannabaceae (e.g. Cannabis sp.), Fabaceae, Poaceae, Polygonaceae (e.g. Persicaria wallichii, Rumex sp.) and Ranunculaceae. It also co-occurs with several congeners, including I. radiata, I. scabrida and I. sulcata (Tanner et al., 2014b).

\subsection{Response to abiotic factors}

312 The species clearly prefers moist to wet soils. A high soil moisture is especially favourable for

313 germination, which furthermore requires more or less bare soil. Germination, seedling establishment and survival are consequently facilitated by some disturbance as frequently found along rivers and shorelines. However, too high soil moisture seemingly reduces $I$. glandulifera cover (Pattison et al., 2019), and early season flooding can strongly reduce

317 seedling survival (Tickner et al., 2001). Measurements of soil moisture have furthermore

318 shown that the species can also grow on soils that are, at least temporarily, relatively dry (Table

319 3) (also indicated by the vegetation types in which it occurs, see part 4.3) (Maule et al., 2000).

320 The species is nonetheless sensitive to drought, which can cause wilting, and has been shown 321 to cause vivid red anthocyanin coloration of plants (Beerling and Perrins, 1993; Fitter and Peat, 322 1994). 

in $\mathrm{CaCl}_{2}$ ) varies between c. 3.4 (Perrins et al., 1993) and 7.5 (Beerling and Perrins, 1993) (Table 3), with an ecological optimum at moderately high values. In exceptional cases, the species was recorded at $\mathrm{pH}$ values of up to $7.6-7.7$ on calcareous deposits (Beerling and Perrins, 1993). While the upper limit appears to be defined by the availability of sites, the lower limit is possibly an effect of increasing aluminium toxicity and low nitrate availability at high soil acidity. The species is nonetheless tolerant to $\mathrm{Mg}$, with a 19-fold variation in soil $\mathrm{Mg}$ concentrations observed for Belgian sites invaded by I. glandulifera (Dassonville et al., 2008). I. glandulifera furthermore shows hypertolerance for cadmium $(\mathrm{Cd})$, with no effects on biomass and germination after exposure to, respectively $150 \mathrm{mg} \mathrm{kg}^{-1}$ and $1000 \mathrm{mg} \mathrm{kg}^{-1} \mathrm{Cd}$ (Coakley et al., 2019).

The species also has a broad range in soil nutrient availability, occurring on sites with both low and high soil $\mathrm{C} / \mathrm{N}$ ratios and cation concentrations (Table 3), but as reflected in the ecology of the main habitats, the species mainly occurs in sites with relatively high soil fertility. The ecological optimum of I. glandulifera at sites with high soil moisture, $\mathrm{pH}$ and fertility (also see part 4.2) may reflect its physiological optimum enabling its high growth.

Although I. glandulifera can occur in open, unshaded vegetation, especially at higher latitudes in Europe, it often occurs in (partly) shaded areas. The species is indeed quite shade tolerant and often found in light Salix and Alnus woodlands, and it can locally be abundant even under closed canopies (Table 3) in forest interiors (Čuda et al., 2020, 2017b; Gaggini et al., 2018; Kostrakiewicz-Gierałt and Zajac, 2014). In fact, I. glandulifera shows an optimum curve along the gradient of light availability, being most frequent and healthy at moderate levels of shade (Čuda et al., 2014; Diekmann et al., 2016; Maule et al., 2000), which coincides with its Ellenberg light value of 5. This is furthermore reflected in the highest population

347 biomass (up to $559 \mathrm{~g}$ dry weight $\mathrm{m}^{-2}$ ) for I. glandulifera growing in locations with 20-30\% 
relative irradiance compared to more shaded and open populations in England (Andrews et al., 2005). See part 5.9 for its physiological adaptation to shade.

I. glandulifera is sensitive to frost, and late spring and early autumn frost can kill seedlings and adult plants, especially smaller and unsheltered plants (Beerling and Perrins, 1993; Fitter and Peat, 1994). An experimental cold treatment of $1 \mathrm{~h}$ at $-9^{\circ} \mathrm{C}$ on Impatiens seedlings from the Czech Republic indicated that I. glandulifera (57\% seedling survival) is more frost-resistant than I. parviflora (40\% survival), but less than I. noli-tangere (72\% survival) (Skálová et al., 2011). Although it has been suggested that native populations might be more frost-resistant than European populations, this has not yet been formally tested (Beerling and Perrins, 1993). Disturbances, such as mowing, can lead to mortality of adult plants and negatively impact population dynamics, if the disturbance occurs before seed dispersal (Beerling and Perrins, 1993).

360

361

\section{Life cycle and biology}

$362 \quad$ 5.1. Life cycle

363 I. glandulifera is a summer-annual herb (therophyte, according to the Raunkiær classification). Reproduction occurs exclusively through sexual reproduction, without clonal propagation (Helmisaari, 2010). Population persistence and establishment is consequently fully dependent on annual seed germination (see also part 5.4). Although seedling densities can be up to 350

367 individuals $\mathrm{m}^{-2}$, density-dependent seedling mortality and plant growth usually results in lower 368 densities in adult I. glandulifera stands (see part 5.2) (Beerling and Perrins, 1993). This dependence of population persistence on annual seed germination has made the species vulnerable to boom-bust dynamics (cf. Strayer et al. 2017), i.e. strong population size

371 fluctuations (Diekmann et al., 2016; Helsen et al., 2019). For example, across 80 permanent 372 vegetation plots monitored between 1989 and 2001 in Germany, I. glandulifera showed strong 
373 colonization of reed communities in certain years, followed by total regression in following 374 years (Kasperek, 2004). These fluctuations were related to changes in the ground-water table 375 and river flooding events (Kasperek, 2004). In another German study, I. glandulifera 376 abundance changed with more than $30 \%$ after 1 year for $10 \%$ of the 114 studied plots

377 (Bieberich et al., 2020). These dynamics can also cause populations to 'wander' through the 378 landscape from year to year. In the Czech Republic, for instance, the population invasion front advanced $2.0 \pm 1.4 \mathrm{~m}$ after 1 year, followed by a retreat of $3.8 \pm 1.8 \mathrm{~m}$ in the second year (Čuda et al., 2017b).

Concerning the species' growth patterns, plants can grow very fast after germination,

382

383

384

385

386

387 with reported vertical growth of $1.3 \mathrm{~m}$ in 72 days (Perrins et al., 1993), and maximum stem growth rates reaching $3.0 \pm 0.5 \mathrm{~cm}^{-1 a y}{ }^{-1} \mathrm{SE}$ (Fig. 5) (Mujuni et al., 2015; Ugoletti et al., 2011). Plants tend to invest primarily in aboveground biomass and usually obtain around $500 \mathrm{~cm}^{2}$ total leaf area, but can reach up to $2000 \mathrm{~cm}^{2}$ in woodland populations (Tanner et al., 2014b). Root:shoot ratios are consequently relatively low (0.1-0.3), but seem variable between populations, in both the native (India) and invaded (UK) range, and can nevertheless increase to c. 0.65 in response to low nutrient availability (Andrews et al., 2009; Skálová et al., 2012; Tanner et al., 2014b). Reproductive allocation (ratio of reproductive to vegetative biomass) was furthermore found to be higher for populations from more northern latitudes, when grown together in a greenhouse (Helsen et al., 2020a) (also see part 6.3).

\subsection{Spatial distribution of plants within populations}

In Europe, densities in adult I. glandulifera stands can reach up to 100-170 individuals $\mathrm{m}^{-2}$, but more commonly range between 20 and 50 individual $\mathrm{m}^{-2}$ (Čuda et al., 2017a; Greenwood and Kuhn, 2014; Maule et al., 2000; Rusterholz et al., 2014; Tanner et al., 2014b; Titze, 2000). Densities vary between habitat types, and low density populations $\left(<5\right.$ individuals $\left.\mathrm{m}^{-2}\right)$ occur 
across Europe, but seem to be especially common in southern Poland (Kostrakiewicz-Gierałt, 2015; Kostrakiewicz-Gierałt and Zajac, 2014). A similar density range (1-177 individuals $\mathrm{m}^{-2}$ ) has also been observed for invasive populations in Québec (Canada) (Leblanc and Lavoie, 2017). Native (Indian) populations nevertheless show lower densities (20-30 individuals $\mathrm{m}^{-2}$ ), potentially due to population thinning through natural enemy damage of seedlings (Tanner et al., 2014b).

404

405

\subsection{Phenology}

406

In Europe, I. glandulifera seeds germinate synchronously during 1-3 weeks from February to March in the oceanic regions (Beerling and Perrins, 1993; Prowse, 2001) or in March-April in more continental and cooler regions (Čuda et al., 2015; Janczak, 2013; Perglová et al., 2009; Perrins et al., 1993). The cotyledon stage lasts until early April and is followed by rapid shoot extension and leaf expansion (Beerling and Perrins, 1993; Ugoletti et al., 2011). Plants will usually reach their mature height in August (Andrews et al., 2009; Tanner et al., 2014b), but can continue to grow until autumn frosts occur (Kostrakiewicz-Gierałt and Zajac, 2014; Skálová et al., 2012; Willis and Hulme, 2002).

Flowering onset occurs at the end of June in oceanic temperate European regions and in July in continental and northern Europe, and British Columbia (Canada) (Clements et al., 2008; Čuda et al., 2015; Perrins et al., 1993; Tyler et al., 2021). In shaded habitats and under 417 strong competition, the flowering can be delayed by 2-3 weeks (Beerling and Perrins, 1993; 418 Mujuni et al., 2015). Flowering normally continues until autumn frosts in October. In the UK, 419 this results in an average flowering season length of 122 days (Baude et al., 2016; Fitter and 420 Peat, 1994). In a common garden experiment in Denmark, flowering started 65-93 days after 421 seedling emergence, with flowering onset being gradually earlier for plants originating from 422 higher latitudes (Kollmann and Bañuelos, 2004). In a greenhouse experiment, a similar 
423 latitudinal gradient in flowering onset was observed (from approx. 90-120 days after 424 germination), indicating that this variation is genetically regulated (Helsen et al., 2020a). In a greenhouse experiment in Belgium, flowering was exceptionally fast, and most populations flowered within 40-45 days after radicle emergence (unpublished data). In the native range, the species is reported to flower in July and August (eFloras, 2020).

Seeds are released over an extended period from mid-July (UK) or from August (continental Europe) until autumn frosts (Chmura et al., 2013; Perrins et al., 1993; Willis and Hulme, 2004). In the UK, average seed mass increases towards the end of the vegetation season, while the number of seeds per capsule is greatest both at the start and close to the end of the fruiting season (Perrins et al., 1993; Willis and Hulme, 2004).

433

\subsection{Reproduction}

I. glandulifera flowers are hermaphroditic, but markedly protandrous. Stamens create a closed sleeve around the stigma, and pollen deposition can start only after the sleeve covering the stigma has fallen off. The male and female reproductive phases normally last around 24 and 67 hours, respectively. The latter phase can double in length in the absence of pollination (Fitter and Peat, 1994; Titze, 2000; Vervoort et al., 2011). The species has no incompatibility system, and is considered facultative allogamous (Baude et al., 2016; Fitter and Peat, 1994).

441 Cleistogamy does not occur (Beerling and Perrins, 1993; Fitter and Peat, 1994). Experimental 442 autonomous selfing yielded very low fruit set (9.3\%) in a study by Vervoort et al. (2011). Hand 443 self-pollination nonetheless indicated high self-compatibility, with seed viability equally high 444 as for hand cross-pollinated plants $(84.9 \pm 1.0 \%)$. This resulted in a self-fertility index (i.e. 445 proportion fruit/seed set for autonomous selfed and hand outcrossed plants) of $0.12 \pm 0.03$ for 446 fruit set and $0.94 \pm 0.19$ for seed set, and a self-compatibility index (i.e. proportion fruit/seed 
set for hand selfed and hand outcrossed plants) of $0.97 \pm 0.06$ for fruit set and $0.95 \pm 0.02$ for seed set (Vervoort et al., 2011).

The high flower densities (up to 130 flowers $\mathrm{m}^{-2}$ ) observed in large I. glandulifera populations combined with high quantities of pollen $\left(1306 \times 10^{3}\right.$ grains per flower $)$ and nectar (7667.8 $\mu$ g flower $^{-1}$ day $^{-1} \pm 4268.3 \mathrm{SD}$ or $357.0-607.4 \mathrm{~kg} \mathrm{ha}^{-1}$ year $^{-1}$ ) attracts large numbers of pollinators (Baude et al., 2016; Emer et al., 2015; Jabłoński, 1986), mostly honey bees (Apis mellifera), common wasps (Vespa vulgaris), bumblebees (Bombus sp.) and Hemiptera (Bartomeus et al., 2010; Lopezaraiza-Mikel et al., 2007; Nienhuis et al., 2009a; Starý and Tkalcu, 1998; Titze, 2000; Vervoort et al., 2011). While honey bees collect both pollen and nectar, bumblebees and wasps predominantly forage for nectar (Titze, 2000). The nectar has high sugar content (48-53\%) and can result in $>10$ mg sugar flower ${ }^{-1}$ day $^{-1}$ (Chittka and Schürkens, 2001; Titze, 2000). I. glandulifera is consequently more rewarding to pollinators in terms of nectar than any known co-occurring native plant species in Europe (Chittka and Schürkens, 2001). The secretion begins soon after the flower opens and is highest during the morning, decreases during the day and ceases at night (Beerling and Perrins, 1993; Titze, 2000).

Pollen diameters are 20.9-28.3 $\mu \mathrm{m}$ (Fitter and Peat, 1994). In a study by Titze (2000), the average pollen production was $1,580,863 \pm 368,746$ pollen grains per flower, of which, on average $1.66 \%$ of the pollen grains remained in the five pollen chambers at the end of anthesis. Increases in humidity can result in increased pollen tube growth and anoxia of pollen tubes results in the cessation of elongation and bursting within 4 min (Beerling and Perrins, 1993). Under lab conditions, pollen germination (pollen tube development) decreased with age, from $50 \%$ at beginning of anthesis, to only $15 \%$ after 32 hours. Often, pollen grains already start germinating in the pollen chamber or on the pollinator (Titze, 2000). During field observations in Germany, the first pollinator-visit of a flower in female state, resulted in on average 256 
472 pollen grains reaching the stigma, 18 forming a pollen tube and 10 pollen tubes penetrating the 473 stigmatic tissue six hours after the pollinator visit. Stigmas furthermore reached saturation of up to 1200 pollen grains after, on average, 14 pollinator visits (Titze, 2000).

The ovary consists of five fused carpels, with 5-locular, axile placentation and on average eleven ovules per capsule (Titze, 2000). This results in a pollen to ovule ratio of around 144,000 . The pollination of I. glandulifera has been described as highly efficient, especially by bumblebees. A 100\% seed set can happen after one pollinator visit (Nienhuis et al., 2009b), although Titze (2000) found that at least 4 pollinator visits are necessary during the female phase to obtain average seed set of 9 seeds in a field assay. In this same study, flowers were visited 6 times/hour on average, whereas Vervoort et al. (2011) reported a total of 250 pollinator visits during a flower's lifespan. The pollination ecology of I. glandulifera has also been described in detail by Burquez (1988) and Daumann (1967).

Total seed production depends on plant size and number of capsules per plant (Kostrakiewicz-Gierałt and Zajac, 2014; Willis and Hulme, 2004). In gardens, plants can have 280 capsules over a season (Perrins et al., 1993), but in nature plants usually have about 40120 capsules per plant (Kostrakiewicz-Gierałt and Zajac, 2014). Capsules can have (1) 6-10 (20) seeds (Fitter and Peat, 1994; Kostrakiewicz-Gierałt and Zajac, 2014; Perrins et al., 1993; Titze, 2000; Willis and Hulme, 2004). As a result, a single plant can produce (500) 800-1700 (2500) seeds over the extended period of seed release, depending on the biotic and abiotic environment as well as population density and origin (Hodgson et al., 2020; Koenies and 492 Glavac, 1979; Perrins et al., 1993; Willis and Hulme, 2004). This results in high (density 493 dependent) seed rain in autumn across Europe (e.g. 1400 seeds $\mathrm{m}^{-2}$ in the Czech Republic 494 (Skálová and Pyšek, 2009), 5000-6000 seeds $\mathrm{m}^{-2}$ in England (Beerling and Perrins, 1993) and up to 32,000 seeds $\mathrm{m}^{-2}$ in Germany (Koenies and Glavac, 1979)). With increasing resources, $I$. glandulifera invests in more, rather than heavier seeds (Willis and Hulme, 2004). Reproductive 
allocation patterns across latitudes in Europe are explained in part 6.3. In dense I. glandulifera populations, seed rains of 5000-6000 (7977) seeds $\mathrm{m}^{-2}$ have been reported (Beerling and Perrins, 1993; Kleyer et al., 2008).

The seeds are explosively discharged from the capsule when ripe (i.e. ballistochory)

501 (Grime et al., 1988), which transport the majority of seeds up to 1-2 (4) $\mathrm{m}$ from the parental

502 plant, with even distances of 8-10 m being predicted by a seed dispersal model (Beerling and Perrins, 1993; Chapman and Gray, 2012). Seeds are also dispersed by water (hydrochory) along streams and rivers (see part 6.1). Seed mass is highly variable, both within and among populations, with population averages ranging between 2 and $35 \mathrm{mg}$ (Table 1) (Chmura et al., 2013; Čuda et al., 2016; Helsen et al., 2017; Hodgson et al., 2020; Willis and Hulme, 2004).

Seed mass can vary with climate, soil conditions and competition (Chmura et al., 2013; Kostrakiewicz-Gierałt and Zajac, 2014; Maciejewska-Rutkowska and Janczak, 2016; Skálová et al., 2012; Willis and Hulme, 2004).

\subsection{Germination}

512 I. glandulifera seeds have very high germination rates (58-95\% of seeds) (Fitter and Peat, 1994; 513 Janczak, 2013; Kollmann and Bañuelos, 2004; Skálová et al., 2019). Germination rates 514 nonetheless strongly vary among years and populations (Willis \& Hulme 2002), and are higher 515 and more homogeneous under controlled experimental conditions (Perglová et al., 2009; 516 Perrins et al., 1993; Willis and Hulme, 2002). Cold moist stratification of at least 30-45 days 517 at $4-5^{\circ} \mathrm{C}$ is required to break the physiological dormancy (Andrews et al., 2009; Beerling and 518 Perrins, 1993; Perglová et al., 2009). The time of chilling required declines logarithmically 519 with time of dry storage at room temperature (Beerling and Perrins, 1993; Perglová et al., 520 2009). After dormancy is broken, seeds do not re-enter secondary dormancy when dry-stored 
521 (Mumford, 1988). The optimal germination depth in the soil is 5-15 mm (Beerling and Perrins, 1993; Janczak, 2013).

Gibberellic acid, winter minimum temperature and soil nitrogen do not seem to

524 influence dormancy (Andrews et al., 2009; Beerling and Perrins, 1993; Skálová et al., 2019),

525 but seed survival does depend on soil moisture conditions (Janczak, 2013). Seed germination

526 is greater under high irradiance and increased nitrogen availability, both in the field (Skálová et al., 2019) and under laboratory conditions (Andrews et al., 2009). The effect of high nitrogen availability is only visible for seeds subjected to short chilling conditions, suggesting that nitrogen effects will be most important at the southern end of I. glandulifera's range in Europe, where winters are shorter and milder (Andrews et al., 2009). A study in the UK furthermore observed earlier germination of heavier seeds (Prowse, 2001). Republic. However, sub-zero temperatures did not affect seed germination in a field experiment (Skálová et al., 2019). Microclimatic effects likely also explain the earlier emergence of more shallow buried seeds (Beerling and Perrins, 1993).

Fully imbibed (i.e. water-saturated) seeds stored under laboratory conditions at $20{ }^{\circ} \mathrm{C}$ can remain viable for at least 3 years, but the percentage of germination decreases with time (Beerling and Perrins, 1993; Perglová et al., 2009). Also in the field, I. glandulifera is able to create a short-term persistent soil seed bank (Bakker et al., 1996; Beerling and Perrins, 1993;

541 Mumford, 1988; Skálová et al., 2019), with some seeds able to survive up to four years 542 (Skálová et al., 2019). However, some studies observe no or very limited germination and/or 543 dormant seeds after the first winter (Janczak, 2013; Perglová et al., 2009; Perrins et al., 1993).

544 This suggests that the formation of a soil seed bank is dependent on environmental conditions, 
such as flooding, since seeds seem to have a limited ability to survive when submerged in water

546 (Janczak and Zieliński, 2012).

\subsection{Response to competition}

549 While several European native species seemingly have no competitive effects on I. glandulifera 550 (e.g. Arabidopsis thaliana, Chelidonium majus, Tanacetum vulgare) (Power and Sánchez 551 Vilas, 2020), more competitive European species, such as Urtica dioica can reduce I. glandulifera's biomass (Čuda et al., 2015; Gruntman et al., 2014), reproductive output (Gruntman et al., 2014) and seedling recruitment and survival (Bastl et al., 1997; Čuda et al., 2015; Prowse, 2001; Tickner et al., 2001). Experimental work also showed that $I$. glandulifera's growth and reproduction is more strongly reduced by graminoid-dominated vegetation than by riparian herb-dominated vegetation (Fig. 5) (Mujuni et al., 2015). Dense native vegetation was even found to prevent the establishment of I. glandulifera on Scottish river banks (Pattison et al., 2019). Competition can furthermore reduce I. glandulifera's plant height and leaf dry matter content (LDMC) and increase its leaf area and specific leaf area

560 (SLA) (Helsen et al., 2018a; Koenies and Glavac, 1979), reflecting trait responses to competition for light.

Despite the observed competitive effects on I. glandulifera, the species nevertheless often appears to be the more dominant competitor in its European range, which is reflected in

564 strong competitive effects on co-occurring species. The species has shown to reduce both 565 above- and belowground growth and biomass of several co-occurring herbaceous species 566 (Beerling and Perrins, 1993; Bieberich et al., 2018; Bottollier-Curtet et al., 2013), including its 567 congeners I. noli-tangere and I. parviflora (Čuda et al., 2015; Skálová et al., 2013). The 568 reproductive output (Chittka and Schürkens, 2001; Gruntman et al., 2014) and seedling survival 569 (Ruckli et al., 2014b) of co-occurring species is also often reduced. I. glandulifera furthermore 
showed negative effects on tree seedling growth in some studies (Maule et al., 2000; Ruckli et al., 2014b), but not in others (Ammer et al., 2011). Effects on plant community level diversity and composition are explained in detail in part 7.1.

Several mechanisms contribute to the competitive success of I. glandulifera and enable this species to achieve dominance in many European plant communities and habitats. First, $I$. glandulifera is a tall statured plant exhibiting several resource acquisitive functional traits (Helsen et al., 2020b; Van Cleemput et al., 2020a), indicating adaptation to fast growth and fast pre-emption of most available light and nutrients (cf. the leaf economics spectrum, Díaz et al. (2016); Wright et al. (2004)). The early synchronized seed germination and fast seedling growth likely further increase the species' success, allowing it to pre-empt resources before the co-occurring species finish their development (Beerling and Perrins, 1993). An experiment with Urtica dioica furthermore showed that I. glandulifera was more tolerant to nutrient deprivation than the competitive European-native $U$. dioica, thus suggesting an additional competitive advantage under low nutrient conditions (Beerling and Perrins, 1993). It has been hypothesized that I. glandulifera's competitive success might be partly caused by its allelopathic capacities (see part 5.10), against which plants in its introduced range are not adapted (cf. the novel weapons hypothesis, Callaway and Ridenour (2004)). This mechanism has been invoked to explain observed negative effects of direct competition and soil legacy effects of I. glandulifera on the growth and survival of European plant species (Gruntman et al., 2014; Power and Sánchez Vilas, 2020), and their arbuscular and ecto-mycorrhizal symbionts (Gaggini et al., 2019a; Ruckli et al., 2014b; Tanner and Gange, 2013). Also the reduced number of herbivores and parasites in I. glandulifera's invaded range compared to its native range (see part 5.7) might allow the plants to allocate more resources to growth and

593 reproduction, thus enhancing their competitive capacity (cf. the 'enemy release' hypothesis,

594 Keane (2002)) (Najberek et al., 2018). 


\subsection{Herbivores and pathogens}

597 I. glandulifera experiences much lower levels of leaf damage by natural pests and invertebrate 598 herbivory in invasive UK populations ( $<15 \%$ of leaves damaged) than in native Indian 599 populations (up to $65 \%$ of leaves damaged) (Tanner et al., 2008, 2014b). Recent field studies 600 in Poland, however, found similar levels of herbivore/pest damage of I. glandulifera leaves 601 than of (native) I. noli-tangere leaves (Najberek et al., 2020a, 2017). The pressure of 602 herbivores/pests varied across several Central European populations, with old populations 603 (established 65-85 years ago) subject to higher levels of leaf damage and aphid pressure than 604 recently established populations (5-25 years old) (Gruntman et al., 2017). Moreover, these 605 older populations showed a greater production of a specific naphthoquinone that acts as a 606 secondary defence compound against herbivory (Gruntman et al., 2017) (see part 5.10).

607 Detailed assessments of herbivore and pest damage of I. glandulifera leaves in one lowland 608 (290 m a.s.l) and one mountain population (909 m a.s.1.) in the Polish Tatra Mountains 609 nonetheless showed that respectively $58 \%$ and $45 \%$ of leaves showed at least one disease or 610 damage symptom. Observed symptoms included spots, necrosis, mines, discoloration, 611 deformation, wilting and herbivory damage (Najberek et al., 2020a, 2017). Experimental work

612 using fungicide and insecticide treatments suggest that generalist invertebrate herbivores and 613 pests have little negative effects on I. glandulifera's fitness in Switzerland (Burkhart and 614 Nentwig, 2008). Both sheep and cattle are known to graze on all aboveground parts (Beerling 615 and Perrins, 1993). Detailed information on invertebrate herbivores, and fungal and viral 616 parasites is provided in the following sections.

617

\section{Invertebrates}


619 In its native range, several invertebrate feeders have been observed on I. glandulifera, including 620 the beetles Altica himensis, Alcidodes westermanni, Languriophasma cyanea and Metialma

621 scenica, the leafhopper Evacanthus repexus and the thrip Taeniothrips major (Tanner et al., 622 2008; Tanner and Djeddour, 2010). Also in Europe, several invertebrate taxa have been 623 observed on I. glandulifera leaves, of which the majority was classified as putative herbivores 624 (Table 4) (Beerling and Perrins, 1993; Najberek et al., 2020a, 2017). However, only a few 625 species have been clearly identified as herbivores of I. glandulifera in Europe, including the Hemiptera (aphids) Aphis fabae, A. nasturtii and Impatientinum asiaticum (Beerling and Perrins, 1993; Starý et al., 2014), the Hymenoptera saw fly Siobla sturmii, the Diptera leafminer fly Phytoliriomyza melampyga (Ellis, 2020; Fitter and Peat, 1994) and the Lepidoptera Deilephila elpenor, Xanthorhoe quadrifasiata and Pristerognatha fuligana, the latter a specialist species of the European native Impatiens noli-tangere (Burkhart and Nentwig, 2008;

631 Gruntman et al., 2017; Lemurell, 2018; Meert and Nossent, 2019). Although Impatientinum balsamines has also been reported to feed on I. glandulifera (Beerling and Perrins, 1993), a more recent study found this species exclusively feeding on I. noli-tangere in Czech Republic

634 (Starý et al., 2014). Prowse (2001) also observed severe leaf damage and reduction of flowering due to grazing by Orthotylus capsid bugs in the UK. Grazing by certain gastropods, including Arion sp. has been observed on cotyledons, seedlings and senescent leaves, but not on mature 637 plant tissue, likely due to the production of secondary compounds (see part 5.10) (Prowse, 638 2001; Ruckli et al., 2013).

641 In I. glandulifera's native range, several mildews (Plasmopara obducens, Sphaerotheca 642 balsaminae), Coelomycetes fungi (Phomopsis sp., Phoma exigua, Ascochyta sp.), 643 Dothideomycetes fungi (Septoria sp.) and rust fungi (Puccinia komarovii var. glanduliferae) 
644 form important pathogens (Tanner et al., 2008, 2014a; Tanner and Djeddour, 2010; Tanner, 645 2007). Mildew (i.e. Plasmopara obducens, Fibroidium balsaminae and potentially 646 Podosphaera balsaminae) and rust damage (i.e. Cronartium flaccidum) also occurs in 647 European populations (Ellis, 2020; Fitter and Peat, 1994; Tanner et al., 2008), with the latter 648 being the most commonly observed leaf damage type (80-90\% of all damaged leaves) in two 649 Polish populations (Najberek et al., 2020a, 2017). Seeds of I. glandulifera in Italy and 650 Switzerland were furthermore found to be infected by the true fungal seed pathogen Fusarium 651 culmorum and several secondary fungal pathogens (Alternaria alternata, Aspergillus niger, 652 Cladosporium cladosprioides, C. herbarum, Epicoccum nigrum, Penicillium notatum, Phoma 653 leveillei and Trichoderma viridae) (Najberek et al., 2018).

654

\section{Viruses}

656 Kollmann et al. (2007) found accidental viral infections of I. glandulifera individuals 657 originating from different regions across Europe, grown in a common garden in Denmark. The 658 infection frequency was region specific, but not related to the population's latitudinal origin. 659 The infection was systemic and could be transferred to different plant species. Although the 660 virus remained unidentified, it caused symptoms resembling those of the Tobacco Rattle Virus. 661 Plants with viral infection symptoms have also been observed in the UK, most likely through 662 infection of the Tomato Spotted Wilt Virus (TSWV), which seemingly caused up to $70 \%$ 663 seedling mortality. Symptoms were furthermore similar to those of Impatiens Necrotic Spot 664 Virus, which is known from horticultural varieties of Impatiens sp. (Prowse, 2001) 665

\section{$666 \quad$ 5.8. Symbionts}

667 In the MycoFLor (Hempel et al., 2013) and FungalRoot databases (Soudzilovskaia et al., 2020), 668 I. glandulifera is classified as (facultative) arbuscular mycorrhizal, based on observations of 
669 vesicular-arbuscular mycorrhiza in British (Harley and Harley, 1987) and Czech (Štajerová et 670 al., 2009) material. Arbuscular mycorrhizal fungi (AMF) root colonisation percentage was 671 furthermore slightly higher for two native Indian populations ( $\pm 80 \%$ average) than three 672 invasive British populations ( $\pm 60 \%$ average) (Tanner et al., 2014b). British, but not Indian 673 populations, showed negative correlation between AMF colonisation percentage and plant 674 height, total leaf area and aboveground biomass, suggesting that association with incompatible 675 AMF species can negatively impact I. glandulifera's fitness in the invaded range (Tanner et 676 al., 2014b). In a pot experiment, AMF inoculation was furthermore found to reduce $I$. 677 glandulifera's biomass of separately grown plants, but to enhance biomass when grown in 678 inter- and intra-specific competition (Ab Razak, 2019). Plant-soil feedbacks (soil conditioning 679 by $I$. glandulifera plants that result in changes in the soil microbial community) seemingly 680 decreased mean root AMF colonisation from 44.6 to $22.8 \%$ compared to unconditioned soil 681 (Pattison et al., 2016). greenhouse conditions, but endophyte communities are nonetheless species poor (Currie et al., 2020; Pattison et al., 2016). Plant-soil feedbacks furthermore increased endophyte species richness and the abundance of certain endophyte species (Pattison et al., 2016). Leaf endophytes have previously been found to protect plants against pathogens and insect herbivores, thus potentially increasing I. glandulifera fitness (Ab Razak, 2019; Currie et al., 2020; Gange et al., 2012).

689

\subsection{Physiological data}

691 I. glandulifera's preference for shaded locations is reflected in its shade-adapted trait set, such 692 as a low leaf mass ratio and leaf area ratio (i.e. total leaf mass/leaf area per aboveground 693 vegetative mass, respectively), and high SLA and photosynthetic rate (Ugoletti et al., 2011). 
694 However, compared to the highly shade-tolerant I. parviflora, I. glandulifera's traits indicate

695

696

697

698

699

700

701

702

703

704

705

706

707

708

709

710

711

712

713

714

715

716

717 adaptation to only moderate levels of shading (Ugoletti et al., 2011).

Experimental shading results in both shade avoidance (i.e. increased height, reduced root:shoot ratio and basal diameter) and shade tolerance responses (i.e. increased leaf area, leaf area ratio, leaf mass ratio and SLA) (Andrews et al., 2009; Gruntman et al., 2020). This is supported by both field and experimental observations of increased plant height in the shaded populations (Kostrakiewicz-Gierałt and Zajac, 2014; Maule et al., 2000; Skálová et al., 2013, 2012), but see Kostrakiewicz-Gierałt (2015) who reported a decrease in plant height in very deep shade of a riparian forest interior. Plants also show physiological shade tolerance during experimental shading, through an increase in maximal photosynthetic efficiency, quantum efficiency and effective quantum yield of PS-II, under low light availability (Gruntman et al., 2020). Although some minor differences occurred, these trait responses to shading were generally comparable for I. glandulifera individuals from the native and invaded range (Gruntman et al., 2020). Not only relative irradiance (shade quantity), but also shade quality (red:far-red ratio) impacts I. glandulifera's shade response. In a shading experiment, plants showed significantly higher increase in SLA and leaf area ratio under canopy shade compared to neutral shade using aluminium shading nets (50\% lower red:far-red ratio for canopy shade). Plants furthermore had reduced chlorophyll levels under canopy shade, compared to both exposed and neutral shaded plants (Strømme, 2012).

Even under $10 \%$ relative irradiance, I. glandulifera can manage to retain fast apical extension growth, thanks to the accumulation of nitrate and potassium in the stems to retain osmotic pressure (up to $20 \%$ of the stem dry weight) (Andrews et al., 2009, 2005). This strategy can result in an osmotic concentration of 168 osmol m $\mathrm{m}^{-3}$ and a water content of $95.8-97.3 \%$ in the stems. It has been calculated that the energetic cost of using $\mathrm{KNO}_{3}$ as osmoticum at low 
irradiance is two to seven times more energetically efficient compared to alternative organic, photosynthesis-dependent osmotica such as hexose, glucose and malate (Andrews et al., 2005).

Several of I. glandulifera's leaf traits, such as high maximum photosynthetic rate $(>20$ $\mu \mathrm{mol} \mathrm{CO} 2 \mathrm{~m}^{-2} \mathrm{~s}^{-1}$ ), SLA, chlorophyll content and leaf nitrogen content (Table 1) (Andrews et al., 2009; Helsen et al., 2020b; Ugoletti et al., 2011; Van Cleemput et al., 2020a) are furthermore linked to a fast growth and resource-acquisitive strategy (cf. the leaf economics spectrum, Díaz et al. (2016); Wright et al. (2004)). This fast growth is likely further promoted by the accumulation of boron (B), which helps with $\mathrm{P}$ uptake, and $\mathrm{Cu}$, which is involved in photosynthesis and plant metabolism (Čuda et al., 2017b; Dassonville et al., 2008; Greenwood et al., 2020). The species' fast growth is likely also related to its relatively high stomatal conductance (Gs, >400 mmol m $\mathrm{m}^{-2} \mathrm{~s}^{-1}$ ), and thus increased photosynthesis, compared to other Impatiens species in Europe. I. glandulifera nevertheless has similar levels of assimilation per unit Gs (A/Gs, c. $0.03 \mu \mathrm{mol} \mathrm{CO} \mathrm{mmol}^{-1}$ ) as other Impatiens species in Europe (Ugoletti et al., 2011). I. glandulifera is a $\mathrm{C}_{3}$ plant in terms of its carbon fixation strategy (Fitter and Peat, 1994).

An overview of other nutrient levels in I. glandulifera leaves is provided in Table 1 for Belgium and in Beerling and Perrins (1993) for England. I. glandulifera also contains high levels of water in leaves (c. 84.3\%), stems (c. 92.7\%) and even roots (c. 75.2\%) (Beerling and Perrins, 1993; Van Meerbeek et al., 2015), which is also reflected in its low values for leaf dry matter content and stem specific density across Europe (Table 1). Experimental nutrient deprivation furthermore induces similar symptoms in I. glandulifera, as observed for several other laboratory grown plants (Table 5) (Prowse, 2001). Concentrations of organic components, such as carbohydrates, starch, cellulose and lignin, are provided in Beerling and Perrins (1993), while foliar pigment concentrations (chlorophyll and carotenoids) are provided in Table 1. 


\subsection{Biochemical data}

745 Aboveground parts of I. glandulifera contain a dozen identified polyphenols, including several

746 flavonoids and phenolic acids with moderate antibiotic and antioxidant activities (Szewczyk et 747 al., 2019, 2016; Vieira et al., 2016). Anti-microbial peptides (Miazga-Karska et al., 2017) and 748 several slightly cytotoxic and antioxidant fatty acids, triterpenoids and sterols (Szewczyk et al., 2018) have been identified in above- and belowground plant parts. Flowers and seed capsules also contain an unsaturated fatty acid (trans-tetradec-2-enoic acid), that relates to specific Apis mellifera queen pheromones (Ortin and Evans, 2013). Five polyphenols, including ampelopsin, have been identified in I. glandulifera pollen with expected medicinal properties, potentially explaining the reduced infection of Bombus pascuorum bumblebees by Apicystis bombi when foraging on I. glandulifera (Vanderplanck et al., 2019).

I. glandulifera furthermore has allelopathic capacity, widely believed to be caused by the high concentrations of several naphthoquinone pigments present in all plant parts (Bieberich et al., 2018; Block et al., 2019; Lobstein et al., 2001). Naphthoquinones reach the highest concentrations in seedlings and gradually decline with plant age, and are furthermore found to be released from I. glandulifera plants by exudation from roots and leaching from leaves (Ruckli et al., 2014a; Smith, 2013). Isolates of these naphthoquinones directly inhibit (nectar) fungal growth and insect development (Block et al., 2019; Mitchell et al., 2007). Recently, other potential allelopathic substances have been isolated, including the unstable 1,2,4-trihydroxynaphthalene-1-O-glucoside and the glucosylated steroids glanduliferin A \& B, with the latter exhibiting (human cancer) cell growth inhibition capacities (Cimmino et al., 2016; Tř́ska et al., 2013). 
controlled experiments using extracts and leachates of different I. glandulifera plant parts

769 (Baležentienè, 2018; Bieberich et al., 2018; Csiszár et al., 2013; Loydi et al., 2015; Vrchotová

et al., 2011). Similar experiments also showed inhibition of these extracts on ectomycorrhizal

771 fungi mycelium development (Ruckli et al., 2014a). Both a field and a greenhouse experiment,

772 however, found no stronger allelopathic effect of I. glandulifera than of European native plant

773 species, suggesting that allelopathy does not strongly contribute to I. glandulifera's invasion success (Del Fabbro et al., 2014; Gruntman et al., 2014). In a greenhouse competition experiment, I. glandulifera's performance was higher in the presence of its litter, although this litter did not reduce the growth of co-occurring plant species (Mujuni et al., 2015). Leaf extracts were furthermore found to strongly increase repellency and mortality of Myzus persicae aphids in a controlled experiment (Pavela et al., 2009).

779

780

\subsection{Genetic data}

781

I. glandulifera is a diploid species throughout its native and invaded range (Song et al., 2003).

782 Chromosome numbers of both $2 \mathrm{n}=20$ and $2 \mathrm{n}=18$ have been reported from multiple locations

783 in both the native and invaded ranges (Singhal et al. 2017; Song et al. 2003, and references 784 therein), with a 2C DNA content of 2.2-2.3 pg for plants with $2 \mathrm{n}=18$ (Fitter and Peat, 1994). In addition, $2 \mathrm{n}=12$ has been reported from India (Jeelani et al., 2010). Multiple studies have furthermore identified polymorphic microsatellite (SSR) markers for the species (Korpelainen and Pietiläinen, 2020; Provan et al., 2007; Walker et al., 2009) and chloroplast genome sequencing has also proven successful and informative for introduction history assessments (Cafa et al., 2020; Kurose et al., 2020).

790 


\section{History of invasive spread in Europe}

792

793

794

795

796

797

798

799

800

801

802

803

804

805

806

807

808

809

810

811

812

813

814

815

\subsection{Pathways of spread}

After I. glandulifera was intentionally introduced as an ornamental and nectar-producing plant in Europe (Adamowski, 2008; Jernelöv, 2017; Pyšek and Prach, 1995), initial naturalisation occurred mainly through escape from gardens (Fig. 6) (Hejda and Pyšek, 2006). This was facilitated by I. glandulifera's high propagule pressure, combined with its ballistic seed dispersal (see part 5.4). Naturalization was in some regions helped by the intentional release in grasslands and along riverbanks by beekeepers and the general public (Pihl, 1884; Rotherham, 2001).

Long-distance dispersal mostly occurs through (downstream) flowing water along river courses, since fresh seeds can roll on the river bed and dry seeds are buoyant and can float long distances (Fig. 6) (Čuda et al., 2017a; Najberek et al., 2020b). As such, waterways serve as major invasion corridors in the landscape (Pyšek and Prach, 1995). Due to the potential of longdistance dispersal, catchment colonization events have corresponded to major steps in the spread of I. glandulifera (Wadsworth et al., 2000). Waterways further serve as corridors for the invasion of adjacent non-riparian habitats, like grasslands and forest ecosystems (Čuda et al., 2020; Pyšek and Prach, 1993). Dispersal away from riverbanks happens predominantly through ballistochory, but flood events can also promote invasion of adjacent lands by inducing seed transport and creating open habitat patches and favourable nutrient conditions for seedling establishment (Čuda et al., 2017a). In Czech Republic, I. glandulifera takes around 20 years from initial establishment on a main river to start spreading along its tributaries (Malíková and Prach, 2010).

Other secondary vectors accounting for long-distance dispersal include human machineries (e.g. mower, tractor wheels), mud on workers' boots (Dawson and Holland, 1999), and transportation of garden waste, contaminated top soil or river gravel (Fig. 6) (CABI, 2020; 
816 Hartmann, 1995; Jernelöv, 2017; Kurtto, 2000; Rusterholz et al., 2012). These secondary

817 dispersal events likely explain the observed gradual upstream migration of the species along

818 mountain streams such as in the Carpathians (Zając et al., 2011). Increasing anthropogenic

819 disturbances of natural habitats furthermore favour the establishment of I. glandulifera in non-

820 riparian habitats, such as forests (Čuda et al., 2020), and possibly roadsides (Follak et al., 2018).

821 Spread of seeds by animals (e.g. rodents, ants) has been suggested, but remains uncertain 822 (Beerling and Perrins, 1993; Helmisaari, 2010). I. glandulifera's introduction history has been 823 explained in part 4.1.

824 It has been hypothesized that the exponential invasion in riparian habitats of Central

825 Europe in the last decades is caused by the cessation of traditional riverbank management 826 practices (mowing, hay making, grazing) since the late 1930s. Together with river 827 eutrophication, this resulted in the replacement of grass and sedge dominated vegetation by 828 vegetation composed of competitive nitrophilous forbs (e.g. Urtica dioica). The absence of a 829 dense sward in these new communities likely facilitated I. glandulifera's establishment 830 (Jernelöv, 2017; Mujuni et al., 2015; Pyšek and Prach, 1995).

831

\subsection{Population genetics}

Multiple introductions of I. glandulifera into Europe have been suggested, and seem supported by observed genetic clustering shown among countries (Hagenblad et al., 2015; Kupcinskiene et al., 2015; Nagy and Korpelainen, 2015), but in some instances also within countries

836 (Hagenblad et al., 2015; Kurose et al., 2020; Love et al., 2013; Nagy and Korpelainen, 2015; 837 Zybartaite et al., 2011). This diverse population origin seems furthermore to be derived from 838 both India and Pakistan (Kurose et al., 2020; Nagy and Korpelainen, 2015). Canadian 839 populations studied genetically by Nagy and Korpelainen (2015) clustered together with British 840 and Finish populations, which supports the hypothesis that Canadian plants have originated 
from Europe. Despite these multiple introductions, many, but not all, European populations

842 show a reduction in (neutral) genetic diversity compared to that of native populations

843 (Hagenblad et al., 2015; Nagy and Korpelainen, 2015). However, note that only a limited

844 number of (native) populations were evaluated in these studies.

845 A resampling study along a European latitudinal gradient found that I. glandulifera

846 populations experienced no genetic diversity loss after 5 years, despite fluctuations in

847 population sizes (Helsen et al., 2019). The study furthermore observed that annual population

848 re-establishment is effectuated by a sufficiently high number of genetically diverse founders

849 and that significant among-population gene flow occurs (Helsen et al., 2019). Temporal shifts

850 in the genetic composition of populations (cf. founder effects) are common, however, especially for small populations (Helsen et al., 2019; Walker et al., 2009). Genetic studies also support that dispersal along river systems plays an important role for gene flow within the species, under some circumstances even more so than human mediated spread (Love et al., 2013; Walker et al., 2009).

855

856

\subsection{Adaptation}

857 Despite expected low potential for adaptation due to its low population-level genetic diversity 858 (Hagenblad et al., 2015; Nagy and Korpelainen, 2015), two greenhouse experiments found that 859 I. glandulifera shows clear patterns of local adaptation for several life-history traits across its 860 European range. Flowering onset was progressively earlier for populations from higher 861 latitudes in the greenhouse, which is likely an adaptive response to cope with the shorter 862 growing season. Following allocation theory predictions, this was accompanied by a gradual 863 decrease in both plant height and vegetative biomass (Helsen et al., 2020a; Kollmann and 864 Bañuelos, 2004). In contrast to allocation theory predictions, however, reproductive output did 865 not decrease with latitude, but remained constant (Helsen et al., 2020a). These patterns were 
hypothesized to be caused by the stress-gradient hypothesis, which predicts selection for higher reproductive allocation at high latitudes due to higher reproductive uncertainty and reduced levels of competition because of harsher climatic conditions. At lower latitudes, communities invaded by I. glandulifera are indeed characterized by a more competitive trait-composition and Grime C-signature, thus potentially driving selection for increased biomass (competitiveness) (Helsen et al., 2018b). In another greenhouse experiment, I. glandulifera individuals from France were indeed found to impose stronger competitive effects on cooccurring plants from more northern origin (Sweden and Norway) (Helsen et al., 2018a). I. glandulifera's short generation time, absence of a long-term seed bank and considerable gene flow likely explain its potential for relatively rapid genetic adaptation. At smaller spatial scales in Germany $\left( \pm 140 \mathrm{~km}^{2}\right.$ ), however, I. glandulifera did not show genetic adaptation to contrasting habitat types (Pahl et al., 2013). These results suggest that I. glandulifera's successful invasion across its large invaded range might also be partly explained by its potential for fast genetic adaptation. Another study nevertheless showed high phenotypic plasticity of several traits in response to variation in nutrient and water availability levels, which might additionally attribute to its invasive success (Skálová et al., 2012).

A greenhouse experiment with native Indian and invasive Norwegian plants found no difference in vegetative and reproductive traits, nor in their plasticity in response to nitrogen availability. This suggests that the species did not acquire a more competitive trait set after introduction, but that it was pre-adapted for invasion (Elst et al., 2016). A recent greenhouse study nevertheless observed higher reproductive allocation for invasive Central European populations than for native Indian populations (Gruntman et al., 2020). Another study observed similar levels of resistance against a generalist herbivore for native populations and older populations from the invaded range, but lower resistance for young native populations. The 
authors interpret this as that the selection pressure for enemy release in the invaded range might

891 attenuate over time (Gruntman et al., 2017).

892

\section{7. Impact and management}

894 7.1. Impact

895 Although several studies have recorded impacts of I. glandulifera on diversity and ecosystem 896 functioning, these effects often seem context dependent, with many studies actually observing 897 very little to no impact (detailed further), especially in comparison to other invasive species in 898 Europe, such as Reynoutria japonica. Consequently, the perceived severity of I. glandulifera's 899 invasive impact is sometimes questioned (e.g. Flügel, 2017). A recent expert knowledge-based assessment of potential I. glandulifera impact on ecosystem functions and services nonetheless ranked the species as having potentially highly damaging impact on the environment (Martinez-Cillero et al., 2019), reflecting the general perception of I. glandulifera as a problematic invader (Kowarik and Schepker, 1998). The species is consequently included on

904 the list of invasive alien species of Union concern of the European Union and the European 905 and Mediterranean Plant Protection Organisation (EPPO) list of invasive alien plants (Tanner 906 and Gange, 2020).

907

\section{Plant communities}

909 Most studies in Europe find no or limited effects of $I$. glandulifera invasion on plot-level plant

910 species richness of riparian vegetation and woodlands (Čuda et al., 2017b; Diekmann et al., 911 2016; Gaggini et al., 2019b; Hejda et al., 2009; Hejda and Pyšek, 2006; Helsen et al., 2018b;

912 Prowse, 2001). These limited effects might be caused by the relatively low diversity of some

913 of these communities prior to invasion, or because I. glandulifera reaches full height late in the

914 growing season, thus only imposing shade after many co-occurring species have already 
915 completed their life cycle (such as vernal geophytes). Grassland communities in both Poland

916 and the UK and riparian vegetation in one British study have nonetheless shown strong

917 reductions in species richness following invasion (Hulme and Bremner, 2006; Kiełtyk and

918 Delimat, 2019; Prowse, 2001). Evenness is furthermore strongly affected in all invaded

919 communities, with significant changes in community composition (Bieberich et al., 2020; $\breve{C u d a}$

920 et al., 2017b; Diekmann et al., 2016; Gaggini et al., 2019b) and even functional diversity (Hejda

921 and de Bello, 2013). These changes, however, usually reflect changes in species abundances

922 rather than species turnover, with mainly abundance losses of light-demanding species and

923 species with low competitive abilities (Čuda et al., 2017b; Diekmann et al., 2016; Helsen et al.,

924 2018b; Hulme and Bremner, 2006; Kiełtyk and Delimat, 2019). The shading effects are also

925 reflected in the community weighted mean (CWM) functional trait shifts towards higher SLA

926 and lower LDMC (Hejda, 2013; Hejda and de Bello, 2013; Helsen et al., 2018b; Scharfy et al.,

927 2011). In Belgium, CWM SLA was, however, found to increase with higher abundance of $I$.

928 glandulifera (Van Cleemput et al., 2020b). CWM plant height was furthermore reduced in the

929 presence of I. glandulifera in a greenhouse experiment (Helsen et al., 2018a).

930

\section{$931 \quad$ Pollination}

932 The high flower densities observed in large I. glandulifera populations, combined with the high

933 quantities of nectar and pollen produced, attract large numbers of pollinators, mainly

934 bumblebees and bees (see part 5.4). I. glandulifera's extended flowering season in early

935 autumn, at a time of low flower abundance in the native European flora, likely contributes to

936 pollinator survival (Starý and Tkalcu, 1998). Although flower visitation is often much higher

937 for I. glandulifera than for co-occurring species in Europe, I. glandulifera's presence only

938 reduced honeybee, but not bumble bee, visitation rates of co-occurring plant species.

939 Consequently, for most plant species, flower pollen loads and seed set are not affected, despite 
940 the deposition of high levels of I. glandulifera pollen on a subset of these plant species (cf.

941 Calystegia sepium, Circaea lutetiana, Epilobium angustifolium, Epilobium hirsutum, Silene

942 dioica) (Bartomeus et al., 2010; Cawoy et al., 2012; Emer et al., 2015; Lopezaraiza-Mikel et

943 al., 2007; Nienhuis et al., 2009a). Two studies nonetheless found significant reduction in pollen

944 load and seed set for the riparian plant species Stachys palustris and Lythrum salicaria when I.

945 glandulifera was present (Chittka and Schürkens, 2001; Thijs et al., 2012).

946

\section{Invertebrate communities}

948 Invaded British riparian vegetation harboured a reduced abundance of herbivore, detritivore

949 and predator invertebrates in both the foliage-dwelling and ground-dwelling communities, but 950 not in the below-ground communities. Species richness of foliage-dwelling Coleoptera and 951 Heteroptera was furthermore significantly reduced (Tanner et al., 2013). Another study found 952 a similar reduction in the diversity and abundance of ground-dwelling invertebrates in Scottish 953 riparian zones (Seeney et al., 2019). In Switzerland, both Collembola and Acari litter and soil 954 community composition shifted with I. glandulifera forest invasion. Collembola richness and 955 abundance was not affected, however, while Acari abundance was higher under invaded 956 vegetation (Rusterholz et al., 2014). In the same region, gastropod species richness and abundance was also increased in invaded forest plots, most likely due to the higher and more constant soil moisture levels under I. glandulifera (Ruckli et al., 2013).

959

\section{Carbon and nutrient pools and fluxes}

961 I. glandulifera has been found to increase community-level aboveground dry biomass in the 962 field (from 0.68 to $1.00 \mathrm{~kg} \mathrm{~m}^{-2}$, Dassonville et al. (2008)) and in the greenhouse (Helsen et al., 963 2018a). This is likely caused by the high amounts of biomass produced by the invader itself,

964 which was found to be $7.98 \pm 4.58 \mathrm{~kg} \mathrm{~m}^{-2} \mathrm{SD}$ wet biomass and $0.58 \pm 0.32 \mathrm{~kg} \mathrm{~m}^{-2} \mathrm{SD}$ dry 
biomass across fifteen $0.75 \mathrm{~m}^{2}$ areas of densely invaded riparian vegetation in Belgium (Van

966 Meerbeek et al., 2015). Along an invasion gradient in Belgium total aboveground biomass

967 nonetheless decreased (Van Cleemput et al., 2020b). Invader-induced increases in total

968 biomass were furthermore related to both functional traits of I. glandulifera and CWM traits of

969 the invaded communities (Helsen et al., 2018a; Van Cleemput et al., 2020b). Belowground

970 (root) biomass, however, was strongly reduced following invasion, potentially due to

971 allelopathic effects (see part 5.10) (Gaggini et al., 2019b). Invasion increased nutrient stocks

972 (N, P, K, Mg) in the aboveground biomass (Dassonville et al., 2008), which is likely partly due

973 to high nutrient levels in aboveground I. glandulifera parts (cf. K, Mg, P, Andrews et al. (2005);

974 Dassonville et al. (2008)) and increased nutrient levels in co-occurring plant species following

975 invasion (cf. N, Mg, Ca, Van Cleemput et al. (2020b)).

976 Several studies found no effects of I. glandulifera invasion on soil carbon and nutrient

977 levels (Dassonville et al., 2008; Gaggini et al., 2019b; Helsen et al., 2020b), with the exception

978 of increased soil B and $\mathrm{Cu}$ in Czech Republic (Čuda et al., 2017b), increased soil P in Belgium

979 (Van Cleemput et al., 2020b) and reduced soil K in Germany (Diekmann et al., 2016). Although

980 no clear difference in litter decomposition rate was observed in Czech Republic (Čuda et al.,

981 2017b), decomposition rates were significantly higher for invaded than control plots along a

982 latitudinal gradient from northern France (Amiens) to central Sweden (Stockholm). Further

983 north, in central Norway (Trondheim), litter decomposition rates were nonetheless lower in

984 invaded communities (Helsen et al., 2018b). Although invasion effects were partly related to

985 changes in CWM traits that are linked to high litter quality, such as high specific stem density

986 and low LDMC, microclimatic changes and invasion impact on the soil decomposer

987 communities were likely also important (Helsen et al., 2018b). I. glandulifera can indeed

988 strongly impact the bacterial, fungal and invertebrate soil communities, most likely through the

989 root exudation of secondary allelopathic compounds (see part 5.10) (Gaggini et al., 2019a, 
990 2018; Pattison et al., 2016; Rusterholz et al., 2014; Stefanowicz et al., 2019). Because of the 991 species' hypertolerance for $\mathrm{Cd}$, it has also been suggested as a potential candidate for 992 phytoremediation of Cd polluted soils (Coakley et al., 2019).

993

994 Soil erosion

995 Although an initial study suggested increased soil erosion in the riparian zone of a Swiss river, 996 inclusion of additional data of subsequent years of this river and a second river in the UK 997 provided a more nuanced picture (Greenwood and Kuhn, 2014). While increased erosion was 998 observed for around half of the time-points, research indicated much higher sediment fluxes 999 for most time points (Greenwood et al., 2020, 2018). The authors argue that I. glandulifera 1000 most easily colonized riparian zones where localized river-flow conditions concentrate and 1001 deposit sediment and seeds. After colonization, the adventitious root system of $I$. glandulifera 1002 enhances sedimentation of fine sediments. At times of strong water flow fluctuations, those 1003 zones nonetheless become prone to higher-than-background sediment flux and erosion because 1004 of the absent root of I. glandulifera in winter and the competition-induced reduced native 1005 vegetation cover (Greenwood et al., 2020) and possibly root mass (Gaggini et al., 2019b).

1006

1007

\subsection{Management}

1008 Since I. glandulifera is an annual plant with limited seed dormancy, management actions 1009 should aim at preventing seed formation (Dawson and Holland, 1999; Wadsworth et al., 2000).

1010 Best timing for plant removal (uprooting or mowing; the latter when there is a high risk of soil 1011 erosion) is consequently before or at early flowering, the latest before first seed set, since 1012 successful seed set has been observed from plants cut late in the growing season (Clements et 1013 al., 2008). Due to the species' ability to rapidly form large populations from a few individuals, 1014 efficiency of control must be very high (> 99\%) to achieve successful eradication (Wadsworth 
1015 et al., 2000). Consequently, follow-up visits during the growing season are often necessary

1016 (Adriaens et al., 2019). Continued management efforts during three consecutive years are

1017 recommended to make sure no regrowth or new germination occurs at the site (Adriaens et al.,

1018 2019; IRD Duhallow LIFE Report, 2015). Specifically for riparian systems, it is recommended

1019 to plan the management on the river catchment scale, working downstream to avoid upstream 1020 reinvasion through the influx of new seeds (Wadsworth et al., 2000). This is, however, often 1021 complicated due to fragmented land ownership and inaccessible locations (Tanner, 2017).

1022 In forests, eradication is likely easier since recolonization is more limited than along 1023 rivers and I. glandulifera is outcompeted by woody species during succession in some cases 1024 (Čuda et al., 2020). However, here, soil disturbance by logging machinery and transport of soil contaminated by seeds should be minimized to prevent further spread of I. glandulifera in forests (Čuda et al., 2020). Raising public awareness about potential negative impacts, especially among beekeepers and growers of ornamental plants, is essential to increase support for management actions and prevent new infestations (Helmisaari, 2010; Novoa et al., 2017; Tanner and Gange, 2020).

1030

\section{Mechanical control}

1032 Due to I. glandulifera's small and shallow rooting system, hand-pulling is a very effective 1033 management strategy (Adriaens et al., 2019; Leblanc and Lavoie, 2017; Tanner, 2017), but can 1034 result in increased soil erosion if removal leaves river banks bare. For larger stands, mowing 1035 (with handheld machinery or with heavy machinery if soil conditions allow) is a more feasible option. The cut should be as close to the ground as possible (below the lowest node) to avoid

1037 regrowth (Delbart et al., 2010; Howell, 2002). Following removal, the cut plant parts should 1038 be safely disposed or bagged to avoid re-rooting and prevent potential allelopathic leachate 1039 effects (Leblanc and Lavoie, 2017). Čuda et al. (2020) argues that this is likely less important 
1040 for forest populations where re-rooting is less probable due to drier soils and a generally thicker

1041 litter layer compared to riparian habitats. Costs can nevertheless be high for this approach (e.g.

1042 Can $\$ 21,000 \mathrm{ha}^{-1}$ in Québec, Canada) (Leblanc and Lavoie, 2017). Spraying hot water of $80^{\circ} \mathrm{C}$

1043 on the plants has also been tested as a management strategy, but cutting is more time and cost

1044 efficient (Oliver et al., 2020).

1045

1046 Grazing

1047 Grazing is considered a potentially effective management option in grasslands, because sheep,

1048 cattle and horses are known to feed on I. glandulifera and trample the fragile stems (Beerling 1049 and Perrins, 1993; Larsson and Martinsson, 1998; Navchoo and Kachroo, 1995). Moreover, $I$. 1050 glandulifera is unable to invade areas densely covered by grass, which is promoted by 1051 generalist grazers such as cattle (Čuda et al., 2017a). The timing of grazing is crucial for control outcome, however, as grazing during seeding can result in further spread of I. glandulifera seeds through ballistochory and zoochory (Cockel and Tanner, 2011; Matthews et al., 2015).

1054

1055

\section{Chemical control}

1056

Both selective (e.g. 2,4-Dichlorophenoxyacetic acid amine, triclopyr) and non-selective herbicides (e.g. glyphosate) are effective to control I. glandulifera (Beerling and Perrins, 1993; CABI, 2020; Wadsworth et al., 2000). However, the use of herbicides near watercourses should

1059 be avoided due to non-target effects and is often legally restricted (Adriaens et al., 2019;

1060 Clements et al., 2008).

1061

1062 Biological control

1063 In a screening of the natural enemies of I. glandulifera in its native range, a number of insects 1064 and fungal pathogens were identified (Varia et al., 2016). From the natural enemies that were 
1065 prioritized for further investigation (Tanner and Djeddour, 2010; Tanner, 2008), only the rust 1066 fungus Puccinia komarovii var. glanduliferae exhibited sufficiently high host specificity and 1067 was subjected to rigorous pest assessment (Pratt et al., 2013). Initial results from its release in 1068 the UK were promising, although low success rates of infection were observed for some $I$. 1069 glandulifera populations, caused by the high host specificity of the rust (Nagy and Korpelainen, 1070 2015; Tanner et al., 2015; Varia et al., 2016). Although this resulted in complete resistance of 1071 certain $I$. glandulifera populations to the original $P$. komarovii strains from India, these 1072 populations nevertheless showed susceptibility to new P. komarovii strains from Pakistan 1073 (Ellison et al., 2020). Experimental work furthermore suggests that the presence of arbuscular 1074 mycorrhizal and endophytic fungi can reduce I. glandulifera's susceptibility to $P$. komarovii, 1075 as coevolved fungi can offer protection against antagonists, potentially hampering biological 1076 control (Ab Razak, 2019; Currie et al., 2020; Gange et al., 2018). However, confirming the 1077 endophyte-enemy release hypothesis (Evans, 2008), plants in the introduced ranges have low 1078 foliar endophytic fungi diversity, which is promising for the success of biocontrol measures 1079 (Currie et al., 2020). The European phytophagous Lepidoptera Pristerognatha fuligana was 1080 also considered as a potential control agent, but has proven ineffective (Burkhart and Nentwig, 1081 2008).

1082

\section{8. Conclusions}

1084 Although most details of I. glandulifera's morphology and auto-ecology were already 1085 summarised in Beerling and Perrins (1993), important novel insights have been gained in the 1086 last decades. For example, the species' boom-bust population dynamics have been formally 1087 acknowledged in its invaded range, and research has increased our understanding of the 1088 species' biotic interactions, regarding competitors, symbionts, herbivores and parasites. Also 1089 our understanding of the species' functional traits, ecophysiology, genetics and biochemistry 
1090 (allelopathic secondary compounds) has improved significantly. Our study furthermore 1091 provides an update of the species' current distribution across the globe, which has strongly

1092 expanded since the 1990s. We also present an overview of all research relating to the species' 1093 invasive behaviour and ecosystem impact, mainly in Europe. In this respect, for the first time,

1094 we compiled the information on the species' population genetic patterns and adaptation in 1095 Europe.

1096 Despite these significant advances, several gaps in our knowledge do remain.

1097 Especially research on the species' herbivores, pathogens and symbionts remains fragmentary 1098 and also our understanding of I. glandulifera's allelopathic biochemical compounds is still

1099 limited. Furthermore, most research on the species has been performed in Europe, while our

1100 knowledge on the species' ecology and invasive behaviour is less well understood across its 1101 current exotic range in the Americas, Asia and New Zealand, and its native Himalayan range.

1102 Finally, we also do not yet fully know how the species' population dynamics and spread will 1103 be affected by the ongoing changes in the climate system (e.g. in response to warming, 1104 droughts).

\section{Acknowledgements}

1108 We thank Kamil Najberek, Alicia Prowse, Elisa Van Cleemput, Sarah Hertecant, Heather A.

1109 Kelly, Barbara Tokarska-Guzik, Adam Zając \& the editors of the journal Biodiversity:

1110 Research and Conservation for giving approval for the re-use of their data and/or figures and

1111 Hajime Matsushima for information on the species' status in Japan. This research was

1112 supported by the Research Foundation - Flanders (FWO) through funding of the scientific 1113 research network FLEUR (www.fleur.ugent.be), KH (1202817N), KDP (ASP035-19) and SG 1114 (G0H1517N). PDF and PS received funding from the European Research Council (ERC) under 
the European Union's Horizon 2020 research and innovation programme (ERC Starting Grant FORMICA 757833).

\section{References}

1119 Ab Razak, N., 2019. Interactions between symbiotic and pathogenic fungi in the invasive 1120 weed, Impatiens glandulifera (Himalayan balsam). University of London.

1121 Adamowski, W., 2008. Balsams on the offensive: the role of planting in the invasion of

Adamowski, W., Krzysztofiak, A., Dajdok, Z., 2018. Impatiens glandulifera Royle - Karta informacyjna gatunku. Źródło: Generalna Dyrekcja Ochrony Środowiska. Impatiens species, in: Tokarska-Guzik, Brock, J.H., Brundu, G., Child, L., Daehler, C.C., Pyšek, P. (Eds.), Plant Invasions: Human Perception, Ecological Impacts and Management. Backhuys Publishers, Leiden, pp. 57-70. www.projekty.gdos.gov.pl/igo.

Adriaens, T., Branquart, E., Gosse, D., Reniers, J., Vanderhoeven, S., 2019. Feasibility of eradication and spread limitation for species of Union concern sensu the EU IAS Regulation (EU 1143/2014) in Belgium. Report prepared in support of implementing the IAS Regulation in Belgium.

Ammer, C., Schall, P., Wördehoff, R., Lamatsch, K., Bachmann, M., 2011. Does tree seedling growth and survival require weeding of Himalayan balsam (Impatiens glandulifera)? Eur. J. For. Res. 130, 107-116. https://doi.org/10.1007/s10342-010-04130

Anderberg, A.A., Rydin, C., Källersjö, M., 2002. Phylogenetic relationships in the order Ericales s.1.: Analyses of molecular data from five genes from the plastid and mitochondrial genomes. Am. J. Bot. 89, 677-687. https://doi.org/10.3732/ajb.89.4.677

Andrews, M., Maule, H.G., Hodge, S., Cherrill, A., Raven, J.A., 2009. Seed dormancy, 
nitrogen nutrition and shade acclimation of Impatiens glandulifera: Implications for

1141 successful invasion of deciduous woodland. Plant Ecol. Divers. 2, 145-153.

1142 https://doi.org/10.1080/17550870903186256

1143 Andrews, M., Maule, H.G., Raven, J.A., Mistry, A., 2005. Extension growth of Impatiens

1144 glandulifera at low irradiance: Importance of nitrate and potassium accumulation. Ann.

1145 Bot. 95, 641-648. https://doi.org/10.1093/aob/mci059

1146 Artemov, I.A., Zykova, E.Y., 2019. Invasive and potentially invasive plant species in State

1147 Nature Biosphere Reserves of the Altai Republic (Russia). Acta Biol. Sib. 5, 73-82.

$1148 \quad$ https://doi.org/10.14258/abs.v5.i4.7059

1149 Bakker, J.P., Poschlod, P., Strykstra, R.J., Bekker, R.M., Thompson, K., 1996. Seed banks

1150 and seed dispersal: Important topics in restoration ecology. Acta Bot. Neerl. 45, 461-

$1151 \quad 490$.

1152 Baležentienè, L., 2018. Phytotoxicity and allelopathic impact of Impatiens glandulifera.

1153 Biologija 64, 153-159. https://doi.org/10.6001/biologija.v64i2.3738

1154 Balogh, L., 2008. Himalayan balsam (Impatiens glandulifera), in: Botta-Dukát, Z., Balogh,

1155 L. (Eds.), The Most Important Invasive Plants in Hungary. Institute of Ecologt and

1156 Botany, Hungarian Academy of Sciences, Vácrátót, pp. 129-137.

1157 https://doi.org/10.1016/s0262-4079(07)60234-6

1158 Bartomeus, I., Vilà, M., Steffan-Dewenter, I., 2010. Combined effects of Impatiens

1159 glandulifera invasion and landscape structure on native plant pollination. J. Ecol. 98,

$1160 \quad$ 440-450. https://doi.org/10.1111/j.1365-2745.2009.01629.x

1161 Bastl, P.M., Prachl, K., PySek, P., 1997. The effect of successional age and disturbance on

1162 the establishment of alien plants in man-made sites: an experimental approach, in:

1163 Brock, J.H., Wade, M., Pyšek, P., Green, D. (Eds.), Plant Invasions: Studies from North

1164 America and Europe. Backhuys Publishers, Leiden, pp. 191-201. 
1165 Baude, M., Kunin, W.E., Boatman, N.D., Conyers, S., Davies, N., Gillespie, M.A.K.,

1166 Morton, R.D., Smart, S.M., Memmott, J., 2016. Historical nectar assessment reveals the

1167 fall and rise of floral resources in Britain. Nature 530, 85-88.

$1168 \quad$ https://doi.org/10.1038/nature16532

1169 Beerling, D.J., 1993. The impact of temperature on the northern distribution limits of the

$1170 \quad$ introduced species Fallopia japonica and Impatiens glandulifera in North-West Europe.

$1171 \quad$ J. Biogeogr. 20, 45-53.

1172 Beerling, D.J., Dawah, H.A., 1993. Abundance and diversity of invertebrates associated with

1173 Fallopia japonica (Houtt. Ronse Decraene) and Impatiens glandulifera (Royle): two

1174 alien plant species in the British Isles. Entomologist 112, 127-139.

1175 Beerling, D.J., Perrins, J.M., 1993. Biological flora of the British Isles. <i>Impatiens

1176 glandulifera $<\mathrm{i}>$ Royle (<i>Impatiens roylei $<\mathrm{i}>$ Walp.). J. Ecol. 81, 367-382.

1177 https://doi.org/10.2307/2261507

1178 Bieberich, J., Feldhaar, H., Lauerer, M., 2020. Micro-habitat and season dependent impact of 1179 the invasive Impatiens glandulifera on native vegetation. NeoBiota 57, 109-131.

$1180 \quad$ https://doi.org/10.3897/neobiota.57.51331

1181 Bieberich, J., Lauerer, M., Drachsler, M., Heinrichs, J., Müller, S., Feldhaar, H., 2018.

1182 Species- and developmental stage-specific effects of allelopathy and competition of

1183 invasive Impatiens glandulifera on co-occurring plants. PLoS One 13, e0205843.

$1184 \quad$ https://doi.org/10.1371/journal.pone.0205843

1185 Block, A.K., Yakubova, E., Widhalm, J.R., 2019. Specialized naphthoquinones present in 1186 Impatiens glandulifera nectaries inhibit the growth of fungal nectar microbes. Plant

1187 Direct 3, 1-7. https://doi.org/10.1002/pld3.132

1188 Bottollier-Curtet, M., Planty-Tabacchi, A.M., Tabacchi, E., 2013. Competition between 1189 young exotic invasive and native dominant plant species: Implications for invasions 

within riparian areas. J. Veg. Sci. 24, 1033-1042. https://doi.org/10.1111/jvs.12034

1191 Britten, J., 1900. Impatiens roylei in England. J. Bot. 38, 50-51.

1192 Burkhart, K., Nentwig, W., 2008. Control of Impatiens glandulifera (Balsaminaceae) by 1193 antagonists in its invaded range. Invasive Plant Sci. Manag. 1, 352-358.

$1194 \quad$ https://doi.org/10.1614/ipsm-08-090.1

1195 Burquez, J.A., 1988. Studies on nectar secretion. University of Cambridge.

1196 CABI, 2020. Impatiens glandulifera. In: Invasive Species Compendium. Wallingford, UK:

1197 CAB International. [WWW Document]. URL https://www.cabi.org/isc/datasheet/28766 $1198 \quad$ (accessed 7.15.20).

1199 Cafa, G., Baroncelli, R., Ellison, C.A., Kurose, D., 2020. Impatiens glandulifera (Himalayan 1200 balsam) chloroplast genome sequence as a promising target for populations studies. $1201 \quad$ PeerJ 8, e8739. https://doi.org/10.7717/peerj.8739

1202 Callaway, R.M., Ridenour, W.M., 2004. Novel weapons: invasive success and the evolution 1203 of increased competitive ability. Front. Ecol. Environ. 2, 436-443.

1204 Cawoy, V., Jonard, M., Mayer, C., Jacquemart, A.-L., 2012. Do abundance and proximity of 1205 the alien Impatiens glandulifera affect pollination and reproductive success of two sympatric co-flowering native species? J. Pollinat. Ecol. 10, 130-139.

1207 Chapman, D.S., Gray, A., 2012. Complex interactions between the wind and ballistic seed 1208 dispersal in Impatiens glandulifera (Royle). J. Ecol. 100, 874-883.

$1209 \quad$ https://doi.org/10.1111/j.1365-2745.2012.01977.x

1210 Chittka, L., Schürkens, S., 2001. Successful invasion of a floral market. An exotic Asian 1211 plant has moved in on Europe's river-banks by bribing pollinators. Nature 411, 653. $1212 \quad$ https://doi.org/10.1038/35079676

1213 Chmura, D., Csontos, P., Sendek, A., 2013. Seed mass variation in central European 1214 populations of invasive Impatiens glandulifera Royle. Polish J. Ecol. 61, 805-809. 
1215 Cimmino, A., Mathieu, V., Evidente, M., Ferderin, M., Moreno Y Banuls, L., Masi, M., De

1216 Carvalho, A., Kiss, R., Evidente, A., 2016. Glanduliferins A and B, two new

1217 glucosylated steroids from Impatiens glandulifera, with in vitro growth inhibitory

1218 activity in human cancer cells. Fitoterapia 109, 138-145.

1219 https://doi.org/10.1016/j.fitote.2015.12.016

1220 Clements, D.R., Feenstra, K.R., Jones, K., Staniforth, R., 2008. The biology of invasive alien 1221 plants in Canada. 9. Impatiens glandulifera Royle. Can. J. Plant Sci. 88, 403-417. https://doi.org/10.4141/CJPS06040

1223

Coakley, S., Cahill, G., Enright, A.M., O’Rourke, B., Petti, C., 2019. Cadmium

Cockel, C.P., Tanner, R.A., 2011. Impatiens glandulifera Royle (Himalayan Balsam). A Handb. Glob. Freshw. Invasive Species.

Csiszár, Á., Korda, M., Schmidt, D., Šporčić, D., Süle, P., Teleki, B., Tiborcz, V., Zagyvai, G., Bartha, D., 2013. Allelopathic potential of some invasive plant species occurring in Hungary. Allelopath. J. 31, 309-318.

1231 Čuda, J., Rumlerová, Z., Brůna, J., Skálová, H., Pyšek, P., 2017a. Floods affect the abundance of invasive Impatiens glandulifera and its spread from river corridors. Divers. Distrib. 23, 342-354. https://doi.org/10.1111/ddi.12524

1234 Čuda, J., Skálová, H., Janovský, Z., Pyšek, P., 2016. Juvenile biological traits of Impatiens species are more strongly associated with naturalization in temperate climate than their Impatiens species: the roles of environmental factors, population density and life stage. 
1241 Čuda, J., Skálová, H., Janovský, Z., Pyšek, P., 2014. Habitat requirements, short-term

1242 population dynamics and coexistence of native and invasive Impatiens species: A field

1243 study. Biol. Invasions 16, 177-190. https://doi.org/10.1007/s10530-013-0512-1

1244 Čuda, J., Skálová, H., Pyšek, P., 2020. Spread of Impatiens glandulifera from riparian

1245 habitats to forests and its associated impacts: insights from a new invasion. Weed Res.

$1246 \quad 60,8-15$. https://doi.org/10.1111/wre.12400

1247 Čuda, J., Vítková, M., Albrechtová, M., Guo, W.Y., Barney, J.N., Pyšek, P., 2017b. Invasive 1248 herb Impatiens glandulifera has minimal impact on multiple components of temperate 1249 forest ecosystem function. Biol. Invasions 19, 3051-3066. https://doi.org/10.1007/s10530-017-1508-z

Currie, A.F., Gange, A.C., Ab Razak, N., Ellison, C.A., Maczey, N., Wood, S. V., 2020. Endophytic fungi in the invasive weed Impatiens glandulifera: a barrier to classical biological control? Weed Res. 60, 50-59. https://doi.org/10.1111/wre.12396

Dajdok, Z., Anioł-Kwiatkowska, J., Kącki, Z., 2003. Distribution of Impatiens glandulifera Royle along Odra river. Phytogeogr. Probl. synanthropic plants 125-130.

Dassonville, N., Vanderhoeven, S., Vanparys, V., Hayez, M., Gruber, W., Meerts, P., 2008.

Daumann, E., 1967. Zur Bestaubung- und Verbreitungs- okologie dreier Impatiens-Arten. Preslia 39, 43-58.

Dawson, F.H., Holland, D., 1999. The distribution in bankside habitats of three alien invasive plants in the U.K. in relation to the development of control strategies. Hydrobiologia 415, 193-201. https://doi.org/10.1023/A:1003872325274 
1265 Del Fabbro, C., Güsewell, S., Prati, D., 2014. Allelopathic effects of three plant invaders on 1266 germination of native species: a field study. Biol. Invasions 16, 1035-1042.

1267 https://doi.org/10.1007/s10530-013-0555-3

1268 Delbart, E., Pieret, N., Mahy, G., 2010. Les trois principales plantes exotiques envahissantes 1269 le long des berges des cours d'eau et plans d'eau en Région wallonne: description et $1270 \quad$ conseils de gestion mécanique, chimique.

1271 Díaz, S., Kattge, J., Cornelissen, J.H.C., Wright, I.J., Lavorel, S., Dray, S., Reu, B., Kleyer, 1272 M., Wirth, C., Colin Prentice, I., Garnier, E., Bönisch, G., Westoby, M., Poorter, H., 1273 Reich, P.B., Moles, A.T., Dickie, J., Gillison, A.N., Zanne, A.E., Chave, J., Joseph 1274 Wright, S., Sheremet'ev, S.N., Jactel, H., Baraloto, C., Cerabolini, B., Pierce, S., 1275 Shipley, B., Kirkup, D., Casanoves, F., Joswig, J.S., Günther, A., Falczuk, V., Rüger, 1276 N., Mahecha, M.D., Gorné, L.D., 2016. The global spectrum of plant form and function. Nature 529, 167-171. https://doi.org/10.1038/nature16489

Diekmann, M., Effertz, H., Baranowski, M., Dupré, C., 2016. Weak effects on plant diversity of two invasive Impatiens species. Plant Ecol. 217, 1503-1514. https://doi.org/10.1007/s11258-016-0663-0

Drescher, A., Prots, B., 2000. Warum breitet sich das Drüsen-Springkraut (Impatiens glandulifera Royle) in den Alpen aus? Wulfenia 7, 5-26.

Drescher, A., Prots, B., 1996. Impatiens glandulifera Royle im südöstlichen Alpenvorland Geschichte, Phytosoziologie und Ökologie. Mitt. Naturwiss. Ver. Steiermark 126, 145162.

Ebel, A.L., Mikhailova, S.I., 2016. Ecological and biological characteristics of whiteflowered form of invasive species Impatiens glandulifera (Balsaminaceae) (in Russian). Растительный мир Азиатской России 4, 30-37. https://doi.org/10.21782/RMAR19952449-2016-4(30-37) 
eFloras, 2020. Flora of Pakistan. Impatiens glandulifera Royle, Ill. Pl. Himal. Mount. 151. t. 28, f. 2. 1834. R.R. Stewart , 1.c. 465. [WWW Document]. URL http://www.efloras.org/florataxon.aspx?flora_id=5\&taxon_id=242423079 (accessed 8.1.20).

Ellenberg, H., Leuschner, C., 2010. Vegetation Mitteleuropas mit den Alpen: in ökologischer, dynamischer und historischer Sicht (Vol. 8104). Utb.

Ellis, W.N., 2020. Plant parasites of Europe. Leafminers, galls and fungi [WWW Document]. URL https://bladmineerders.nl/hostplants/plantae/spermatopsida/angiosperma/eudicots/superasterids/asterids/ericales/balsa minaceae/impatiens/impatiens-glandulifera/ (accessed 9.23.20).

Ellison, C.A., Pollard, K.M., Varia, S., 2020. Potential of a coevolved rust fungus for the management of Himalayan balsam in the British Isles: first field releases. Weed Res. 60, 37-49. https://doi.org/10.1111/wre.12403

Elst, E.M., Acharya, K.P., Dar, P.A., Reshi, Z.A., Tufto, J., Nijs, I., Graae, B.J., 2016. Preadaptation or genetic shift after introduction in the invasive species Impatiens glandulifera? Acta Oecologica 70, 60-66. https://doi.org/10.1016/j.actao.2015.12.002

Emer, C., Vaughan, I.P., Hiscock, S., Memmott, J., 2015. The impact of the invasive alien plant, Impatiens glandulifera, on pollen transfer networks. PLoS One 10, e0143532. https://doi.org/10.1371/journal.pone.0143532

Ennos, A.R., Crook, M.J., Grimshaw, C., 1993. A comparative study of the anchorage systems of Himalayan balsam Impatiens glandulifera and mature sunflower Helianthus annuиs. J. Exp. Bot. 44, 133-146. https://doi.org/10.1093/jxb/44.1.133

EPPO, 2020. EPPO, 2020. EPPO Global database, Paris, France: EPPO.

Evans, H.C., 2008. The endophyte-enemy release hypothesis: implications for classical biological control and plant invasions, in: Proceedings of the XII International 

$20-26$.

1317 Fayvush, G.M., Tamanyan, K.G., 2011. On distribution of some invasive and expanding 1318 plant species in Armenia and in the Caucasus. Takhtajania 1, 181-185.

1319 Fitter, A., 1978. An atlas of the wild flowers of Britain and northern Europe.

1320 Fitter, A., Peat, H., 1994. The ecological flora database (http://www.ecoflora.co.uk ). J. Ecol. $82,415-425$.

Flügel, H.J., 2017. Das Drüsige Springkraut (Impatiens glandulifera) - Bedrohung oder Bereicherung? Natur und Landschaft 92, 268-273. https://doi.org/10.17433/6.2017.50153477.268-273

Follak, S., Eberius, M., Essl, F., Fürdös, A., Sedlacek, N., Trognitz, F., 2018. Invasive alien plants along roadsides in Europe. EPPO Bull. 48, 256-265. https://doi.org/10.1111/epp.12465

Gaggini, L., Rusterholz, H.P., Baur, B., 2019a. The annual invasive plant Impatiens glandulifera reduces hyphal biomass of soil fungi in deciduous forests. Fungal Ecol. 39, 242-249. https://doi.org/10.1016/j.funeco.2018.12.004

Gaggini, L., Rusterholz, H.P., Baur, B., 2019b. The invasion of an annual exotic plant species affects the above- and belowground plant diversity in deciduous forests to a different extent. Perspect. Plant Ecol. Evol. Syst. 38, 74-83. https://doi.org/10.1016/j.ppees.2019.04.004

Gaggini, L., Rusterholz, H.P., Baur, B., 2018. The invasive plant Impatiens glandulifera affects soil fungal diversity and the bacterial community in forests. Appl. Soil Ecol. 124, 335-343. https://doi.org/10.1016/j.apsoil.2017.11.021

Gange, A., Currie, A., Ab Razak, N., Ellison, C., Maczey, N., Wood, S., Jackson, R., Rabiey, M., 2018. The threat of invasive species to biodiversity: Biological control of Himalayan 
1341 Gange, A.C., Eschen, R., Wearn, J.A., Thawer, A., Sutton, B.C., 2012. Differential effects of 1342 foliar endophytic fungi on insect herbivores attacking a herbaceous plant. Oecologia $1343 \quad 168,1023-1031$.

1344 GBIF Secretariat, 2019. Impatiens glandulifera Royle. GBIF Backbone Taxonomy. Checklist dataset https://doi.org/10.15468/39omei accessed via GBIF.org on 2020-09-22. [WWW Document].

1347 Geuten, K., Smets, E., Schols, P., Yuan, Y.-M., Janssens, S., Küpfer, P., Pyck, N., 2004.

1348 Conflicting phylogenies of balsaminoid families and the polytomy in Ericales: combining data in a Bayesian framework. Mol. Phylogenet. Evol. 31, 711-729.

Greenwood, P., Baumann, P., Pulley, S., Kuhn, N.J., 2018. The invasive alien plant, Impatiens glandulifera (Himalayan Balsam), and increased soil erosion: causation or association? Case studies from a river system in Switzerland and the UK. J. Soils Sediments 18, 3463-3477. https://doi.org/10.1007/s11368-018-2041-0

Greenwood, P., Gange, A.C., Kuhn, N.J., 2020. Evidence of sedimentation inequality along riparian areas colonised by Impatiens glandulifera (Himalayan balsam). Weed Res. 60,

1362 Grey-Wilson, C., 1983. A survey of Impatiens in cultivation. The Plantsman 5, 86-102.

1363 Grime, J.P., Hodgson, J.G., Hunt, R., 1988. Comparative plant ecology: A functional 1364 approach to common British species. Unwin Hyman, London. 
1365 Gruntman, M., Pehl, A.K., Joshi, S., Tielbörger, K., 2014. Competitive dominance of the 1366 invasive plant Impatiens glandulifera: Using competitive effect and response with a 1367 vigorous neighbour. Biol. Invasions 16, 141-151. https://doi.org/10.1007/s10530-013$1368 \quad 0509-9$

1369 Gruntman, M., Segev, U., Glauser, G.G., Tielbörger, K., 2017. Evolution of plant defences 1370 along an invasion chronosequence: defence is lost due to enemy release - but not 1371 forever. J. Ecol. 105, 255-264. https://doi.org/10.1111/1365-2745.12660

1372 Gruntman, M., Segev, U., Tielbörger, K., 2020. Shade-induced plasticity in invasive 1373 Impatiens glandulifera populations. Weed Res. 60, 16-25.

$1374 \quad$ https://doi.org/10.1111/wre.12394

1375 Hagenblad, J., Hülskötter, J., Acharya, K.P., Brunet, J., Chabrerie, O., Cousins, S.A.O.O., 1376 Dar, P.A., Diekmann, M., De Frenne, P., Hermy, M., Jamoneau, A., Kolb, A., Lemke, I., 1377 Plue, J., Reshi, Z. a., Graae, B.J., 2015. Low genetic diversity despite multiple 1378 introductions of the invasive plant species Impatiens glandulifera in Europe. BMC 1379 Genet. 16, 103. https://doi.org/10.1186/s12863-015-0242-8

1380 Harley, J.L., Harley, E.L., 1987. A check-list of mycorrhiza in the British flora. New Phytol. $105,1-102$.

1382 Hartmann, E., 1995. Neophyten: biologie, verbreitung und kontrolle ausgewählter arten. $1383 \quad$ Ecomed-Verlag-Ges.

1384 Hejda, M., 2013. Do species of invaded communities differ in their vulnerability to being 1385 eliminated by the dominant alien plants? Biol. Invasions 15, 1989-1999. https://doi.org/10.1007/s10530-013-0426-y

1387 Hejda, M., de Bello, F., 2013. Impact of plant invasions on functional diversity in the 1388 vegetation of Central Europe. J. Veg. Sci. 24, 890-897.

1389 https://doi.org/10.1111/jvs.12026 
1390 Hejda, M., Pyšek, P., 2006. What is the impact of Impatiens glandulifera on species diversity 1391 of invaded riparian vegetation? Biol. Conserv. 132, 143-152.

1392 https://doi.org/10.1016/j.biocon.2006.03.025

1393 Hejda, M., Pyšek, P., Jarošík, V., 2009. Impact of invasive plants on the species richness, 1394 diversity and composition of invaded communities. J. Ecol. 97, 393-403. https://doi.org/10.1111/j.1365-2745.2009.01480.x

Helmisaari, H., 2010. NOBANIS - Invasive alien species fact sheet: Impatiens glandulifera [WWW Document]. Online database North Eur. Balt. Netw. invasive alien species -

Helsen, K., Acharya, K.P., Brunet, J., Cousins, S.A.O.O., Decocq, G., Hermy, M., Kolb, A., Lemke, I.H., Lenoir, J., Plue, J., Verheyen, K., De Frenne, P., Graae, B.J., 2017. Biotic and abiotic drivers of intraspecific trait variation within plant populations of three herbaceous plant species along a latitudinal gradient. BMC Ecol. 17, 38. https://doi.org/10.1186/s12898-017-0151-y

Helsen, K., Acharya, K.P., Graae, B.J., De Kort, H., Brunet, J., Chabrerie, O., Cousins, S.A.O., De Frenne, P., Hermy, M., Verheyen, K., Pélabon, C., 2020a. Earlier onset of flowering and increased reproductive allocation of an annual invasive plant in the north of its novel range. Ann. Bot. 1-12. https://doi.org/10.1093/aob/mcaa110

Helsen, K., Hagenblad, J., Acharya, K.P., Brunet, J., Cousins, S.A.O., Decocq, G., De Frenne, P., Kimberley, A., Kolb, A., Michaelis, J., Plue, J., Verheyen, K., Speed, J.D.M., Graae, B.J., 2019. No genetic erosion after five generations for Impatiens glandulifera populations across the invaded range in Europe. BMC Genet. 20, 20. https://doi.org/10.1186/s12863-019-0721-4

Helsen, K., Kapás, R.E., Rakvaag, G., Speed, J.D.M., Graae, B.J., 2018a. Impacts of an invasive plant on primary production: Testing a functional trait-based framework with a 
1416 Helsen, K., Smith, S.W., Brunet, J., Cousins, S.A.O., De Frenne, P., Kimberley, A., Kolb, A.,

1417 Lenoir, J., Shiyu, M.A., Michaelis, J., Plue, J., Verheyen, K., Speed, J.D.M., Graae, B.J., 1418 2018b. Impact of an invasive alien plant on litter decomposition along a latitudinal 1419 gradient. Ecosphere 9, e02097. https://doi.org/10.1002/ecs2.2097

1420 Helsen, K., Van Cleemput, E., Bassi, L., Graae, B.J., Somers, B., Blonder, B., Honnay, O., 2020b. Inter- and intraspecific trait variation shape multidimensional trait overlap

Hill, M.O., Preston, C.D., Roy, D.B., 2004. Plantatt - Atributes of British and Irish plants:

Hempel, S., Götzenberger, L., Kühn, I., Michalski, S.G., Rillig, M.C., Zobel, M., Moora, M., 2013. Mycorrhizas in the Central European flora: relationships with plant life history traits and ecology. Ecology 94, 1389-99.

Cons, Huntingdon, UK.

Hodgson, J.G., Marti, G.M., Sera, B., Jones, G., Bogaard, A., Charles, M., Font, X., Ater, M., Taleb, A., Santini, B.A., Hmimsa, Y., Palmer, C., Wilson, P.J., Band, S.R., Styring, A., Diffey, C., Green, L., Nitsch, E., Stroud, E., Warham, G., 2020. Seed size, number and strategies in annual plants: a comparative functional analysis and synthesis. Ann. Bot. early view. https://doi.org/10.1093/aob/mcaa151

Howell, B., 2002. Control \& Eradication of Himalayan Balsam. Q. J. For. 96, 125-127.

Hulme, P.E., Bremner, E.T., 2006. Assessing the impact of Impatiens glandulifera on riparian habitats: Partitioning diversity components following species removal. J. Appl. Ecol. 43, 43-50. https://doi.org/10.1111/j.1365-2664.2005.01102.x

IRD Duhallow LIFE Report, 2015. Removal and monitoring of Himalayan Balsam Impatiens 

glandulifera - Monitoring Report.

1441 Jabłoński, B., 1986. Nektarowanie i wydajność miodowa ważniejszych roślin miododajnych 1442 w warunkach Polski. Część V. Pszczel. Zesz. Nauk. 30, 195-205.

1443 Janczak, B., 2013. Preliminary field studies on survival rate of seeds of invasive terophyte $1444 \quad$ Impatiens glandulifera Royle (Balsaminaceae). Bot. - Steciana 17, 167-176.

1445 Janczak, B., Zieliński, J., 2012. Wybrane aspekty biologii nasion inwazyjnego terofita 1446 Impatiens glandulifera Royle (Balsaminaceae). Stud. i Mater. Cent. Edukac. Przyr. 14.4, $1447 \quad 226-233$

1448 Janssens, S., Geuten, K., Yuan, Y.M., Song, Y., Küpfer, P., Smets, E., 2006. Phylogenetics of $1449 \quad$ Impatiens and Hydrocera (Balsaminaceae) using chloroplast atpB-rbcL spacer $1450 \quad$ sequences. Syst. Bot. 31, 171-180. https://doi.org/10.1600/036364406775971796

1451 Jeelani, S.M., Rani, S., Kumar, S., Gupta, R.C., Kumari, S., 2010. Cytomorphological 1452 diversity in some species of Impatiens Linn. (Balsaminaceae) from Western Himalayas 1453 (India). Cytologia (Tokyo). 75, 379-387. https://doi.org/10.1508/cytologia.75.379

1454 Jernelöv, A., 2017. The long-term fate of invasive species - Aliens forever or integrated 1455 immigrants with time. Springer.

1456 Kasperek, G., 2004. Fluctuations in numbers of neophytes, especially Impatiens glandulifera, in permanent plots in a west German floodplain during 13 years. Neobiota 3, 27-37.

1458 Keane, R., 2002. Exotic plant invasions and the enemy release hypothesis. Trends Ecol. Evol. $1459 \quad 17,164-170$. https://doi.org/10.1016/S0169-5347(02)02499-0

1460 Kiełtyk, P., Delimat, A., 2019. Impact of the alien plant Impatiens glandulifera on species 1461 diversity of invaded vegetation in the northern foothills of the Tatra Mountains, Central $1462 \quad$ Europe. Plant Ecol. 220, 1-12. https://doi.org/10.1007/s11258-018-0898-z

1463 Kleyer, M., Bekker, R., Knevel, I.C., Bakker, J.P., Thompson, K., Sonnenschein, M., 1464 Poschlod, P., van Groenendael, J.M., Klimeš, L., Klimešová, J., Klotz, S., Rusch, G.M., 
Hermy, M., Adriaens, D., Boedeltje, G., Bossuyt, B., Dannemann, A., Endels, P., Götzenberger, L., Hodgson, J.G., Jackel, A.-K., Kühn, I., Kunzmann, D., Ozinga, W. a., Römermann, C., Stadler, M., Schlegelmilch, J., Steendam, H.J., Tackenberg, O., Wilmann, B., Cornelissen, J.H.C., Eriksson, O., Garnier, E., Peco, B., 2008. The LEDA

Klotz, S., Kühn, I., Durka, W., 2002. BiolFlor - Eine Datenbank zu biologisch-ökologischen Merkmalen der Gefäßpflanzen in Deutschland. Schriftenr. Veg. 38, 1-334.

Koenies, H., Glavac, V., 1979. Über die Konkurrenzfähigkeit des Indischen Springkrautes (Impatiens glandulifera ROYLE) am Fuldaufer bei Kassel. Philippia 4, 47-59.

Kollmann, J., Bañuelos, M.J., 2004. Latitudinal trends in growth and phenology of the invasive alien plant Impatiens glandulifera (Balsaminaceae). Divers. Distrib. 10, 377385. https://doi.org/10.1111/j.1366-9516.2004.00126.x

1480 Komzha, A.L., Popov, K.P., 1990. New data on the adventive flora of the North Ossetian autonomous Soviet Republic. Bot. Zhurnal 75, 108-110.

Kopecký, K., 1967. Die flussbegleitende Neophytengesellschaft Impatienti-Solidaginetum in Mittelmähren. Preslia 39, 151-166.

1484 Korpelainen, H., Pietiläinen, M., 2020. New microsatellite marker tools for genotype identification and analyses of genetic relationships in two ornamentals, the popular common lilac (Syringa vulgaris) and the invasive garden escapee Himalayan balsam (Impatiens glandulifera). bioRxiv. https://doi.org/10.1101/2020.03.03.974535

Kostrakiewicz-Gierałt, K., 2015. The effect of habitat conditions on the abundance of populations and selected individual and floral traits of Impatiens glandulifera Royle. 
1491 Kostrakiewicz-Gierałt, K., Zajac, M., 2014. The influence of habitat conditions on the performance of two invasive, annuals - Impatiens glandulifera and Bidens frondosa. Biologia (Bratisl). 69, 449-462. https://doi.org/10.2478/s11756-014-0333-4

Kowarik, I., Schepker, H., 1998. Plant invasions in northern Germany: human perception and response, in: Starfinger, U., Edwards, K., Kowarik, I, Williamson, M. (Eds.), Plant Invasions: Ecological Mechanisms and Human Responses. Backhuys Publishers, Leiden, pp. 109-120.

Kupcinskiene, E., Zybartaite, L., Paulauskas, A., 2015. Comparison of genetic diversity of three Impatiens species from Central Europe and Baltic region. Zemdirbyste-Agriculture

Kurose, D., Pollard, K.M., Ellison, C.A., 2020. Chloroplast DNA analysis of the invasive 102, 87-94. https://doi.org/10.13080/z-a.2015.102.011 weed, Himalayan balsam (Impatiens glandulifera), in the British Isles. Sci. Reports 10, 10966. https://doi.org/10.1038/s41598-020-67871-0

Kurtto, A., 2000. Case studies Himalayan balsam (Impatiens glandulifera), in: Kurtto, A., Tomminen, J., Lepäkoski, E., Nummi, P. (Eds.), Alien Species in Finland. Helsinki, Finland, pp. 25-27.

Larsson, C., Martinsson, K., 1998. Impatiens glandulifera in Sweden-an invasive species or a

1509 Leblanc, M., Lavoie, C., 2017. Controlling purple jewelweed (Impatiens glandulifera):

1510 Assessment of feasibility and costs. Invasive Plant Sci. Manag. 10, 254-621.

$1511 \quad$ https://doi.org/10.1017/inp.2017.21

1512 Lemurell, S., 2018. Vilken Art resource [WWW Document]. URL http://www.vilkenart.se $1513 \quad$ (accessed 9.23.20).

1514 Lhotska, M., Kopecký, K., 1966. Zur Verbreitungsbiologie und Phytozonologie von 

Odra. Preslia 38, 378-385.

1517 Lobstein, A., Brenne, X., Feist, E., Metz, N., Weniger, B., Anton, R., 2001. Quantitative 1518 determination of naphthoquinones of Impatiens species. Phytochem. Anal. 12, 202-205. 1519 https://doi.org/10.1002/pca.574

1520 Lopezaraiza-Mikel, M.E., Hayes, R.B., Whalley, M.R., Memmott, J., 2007. The impact of an alien plant on a native plant- pollinator network : an experimental approach. Ecol. Lett. 10, 539-550. https://doi.org/10.1111/j.1461-0248.2007.01055.x

Love, H.M., Maggs, C.A., Murray, T.E., Provan, J., 2013. Genetic evidence for predominantly hydrochoric gene flow in the invasive riparian plant Impatiens glandulifera (Himalayan balsam). Ann. Bot. 112, 1743-1750. https://doi.org/10.1093/aob/mct227

Loydi, A., Donath, T.W., Eckstein, R.L., Otte, A., 2015. Non-native species litter reduces germination and growth of resident forbs and grasses: allelopathic, osmotic or mechanical effects? Biol. Invasions 17, 581-595. https://doi.org/10.1007/s10530-0140750-x

Maciejewska-Rutkowska, I., Janczak, B., 2016. Variability of seeds of the invasive species Impatiens glandulifera Royle (Balsaminaceae) and their micromorphology. Steciana 20, 183-190. https://doi.org/10.12657/steciana.020.019

Malíková, L., Prach, K., 2010. Spread of alien Impatiens glandulifera along rivers invaded at different times. Ecohydrol. Hydrobiol. 10, 81-85. https://doi.org/10.2478/v10104-0090050-8

Martinez-Cillero, R., Willcock, S., Perez-Diaz, A., Joslin, E., Vergeer, P., Peh, K.S.H., 2019. A practical tool for assessing ecosystem services enhancement and degradation associated with invasive alien species. Ecol. Evol. 9, 3918-3936. 
https://doi.org/10.1002/ece3.5020

1541 Matthews, J., Beringen, R., Boer, E., Duistermaat, H., Odé, B., Van Valkenburg, J., Velde,

1542 G., Leuven, R.S.E.W., 2015. Risks and management of non-native Impatiens species in 1543 the Netherlands.

1544 Maule, H., Andrews, M., Watson, C., Cherrill, A., 2000. Distribution, biomass and effect on native species of Impatiens glandulifera in a deciduous woodland in northeast England. Asp. Appl. Biol. 58, 31-38.

McClatchie, I., 1917. Observations on the root-system of Impatiens roylei, Walp. Bot. J.

Meert, R., Nossent, R., 2019. Impatiens glandulifera as a commonly used host plant for Pristerognatha fuligana (Lepidoptera: Tortricidae) in Belgium. phegea 47, 140-144.

Miazga-Karska, M., Szewczyk, K., Klimek, K., Ginalska, G., 2017. In vitro activity of peptide fractions from Impatiens glandulifera against caries causing bacteria. Acta Pol.

Moor, M., 1958. Pflanzengesellschaften schweizerischer Flußauen. Mitt. Eidg. Anst. Forstl. Versuchswes. 34, 223-361.

Mossberg, B., Stenberg, L., 2018. Nordens Flora. Bonnier Fakta. 
1565 Mucina, L., Bültmann, H., Dierßen, K., Theurillat, J., Raus, T., Čarni, A., Šumberová, K., 1566 Willner, W., Dengler, J., García, R.G., Chytrý, M., Hájek, M., Di Pietro, R., Iakushenko, 1567 D., Pallas, J., Daniëls, F.J.A., Bergmeier, E., Santos Guerra, A., Ermakov, N., 1568 Valachovič, M., Schaminée, J.H.J., Lysenko, T., Didukh, Y.P., Pignatti, S., Rodwell, 1569 J.S., Capelo, J., Weber, H.E., Solomeshch, A., Dimopoulos, P., Aguiar, C., Hennekens, S.M., Tichý, L., 2016. Vegetation of Europe: hierarchical floristic classification system of vascular plant, bryophyte, lichen, and algal communities. Appl. Veg. Sci. 19, 3-264. https://doi.org/10.1111/avsc.12257

Mujuni, N., De Frenne, P., Graae, B.J., 2015. The effect of latitude, litter and vegetation type on the performance of the invasive species Impatiens glandulifera. Norwegian University of Science and Technology.

Mumford, P.M., 1988. Alleviation and induction of dormancy by temperature in Impatiens glandulifera Royle. New Phytol. 109, 107-110. https://doi.org/10.1111/j.14698137.1988.tb00224.x

Nagy, A.-M., Korpelainen, H., 2015. Population genetics of Himalayan balsam (Impatiens glandulifera): comparison of native and introduced populations. Plant Ecol. Divers. 8, 317-321. https://doi.org/10.1080/17550874.2013.863407

Najberek, K., Okarma, H., Chmura, D., Król, W., Walusiak, E., Solarz, W., 2020a. Enemy pressure exerted on alien and native plants may differ between montane and lowland regions. Arthropod. Plant. Interact. 14, 275-287. https://doi.org/10.1007/s11829-01909736-6

Najberek, K., Olejniczak, P., Berent, K., Gąsienica-Staszeczek, M., Solarz, W., 2020b. The ability of seeds to float with water currents contributes to the invasion success of Impatiens balfourii and I. glandulifera. J. Plant Res. 14, 275-287. https://doi.org/10.1007/s10265-020-01212-0 
1590 Najberek, K., Pusz, W., Solarz, W., Olejniczak, P., 2018. The seeds of success: release from 1591 fungal attack on seeds may influence the invasiveness of alien Impatiens. Plant Ecol. 219, 1197-1207. https://doi.org/10.1007/s11258-018-0872-9

1593 Najberek, K., Solarz, W., Chmura, D., 2017. Do local enemies attack alien and native 1594 Impatiens alike? Acta Soc. Bot. Pol. 86, 1-15. https://doi.org/10.5586/asbp.3562

1595 Navchoo, I.A., Kachroo, P., 1995. Flora of Pulwama (Kashmir). Bishen Singh Mahendra Pal Singh.

Nienhuis, C.M., Dietzsch, A.C., Stout, J.C., 2009a. The impacts of an invasive alien plant and

Ortin, Y., Evans, P., 2013. Trans-tetradec-2-enoic acid in Impatiens glandulifera. Synth.

Novoa, A., Dehnen-Schmutz, K., Fried, J., Vimercati, G., 2017. Does public awareness landscape types. Biol. Invasions 19, 3691-3705.

Oberdorfer, E., 1983. Süddeutsche Pflanzengesellschaften. Gustav Fischer Verlag. Stuttgart, Germany.

Oliver, B.W., Berge, T.W., Solhaug, K.A., Fløistad, I.S., 2020. Hot water and cutting for control of Impatiens glandulifera. Invasive Plant Sci. Manag. 13, 84-93. https://doi.org/10.1017/inp.2020.7

1613 Pacanoski, Z., Saliji, A., 2014. The invasive Impatiens glandulifera Royle (Himalayan 1614 balsam) in the Republic of Macedonia: First record and forecast. EPPO Bull. 44, 87-93. 
Pahl, A.T., Kollmann, J., Mayer, A., Haider, S., 2013. No evidence for local adaptation in an invasive alien plant: Field and greenhouse experiments tracing a colonization sequence. Ann. Bot. 112, 1921-1930. https://doi.org/10.1093/aob/mct246

Pattison, Z., Rumble, H., Tanner, R.A., Jin, L., Gange, A.C., 2016. Positive plant-soil feedbacks of the invasive Impatiens glandulifera and their effects on above-ground

Pattison, Z., Vallejo-Marín, M., Willby, N., 2019. Riverbanks as battlegrounds: Why does the abundance of native and invasive plants vary? Ecosystems 22, 578-586. https://doi.org/10.1007/s10021-018-0288-3

Pavela, R., Vrchotová, N., Šerá, B., 2009. Repellency and toxicity of three Impatiens species (Balsaminaceae) extracts on Myzus persicae Sulzer (Homoptera: Aphididae). J. Biopestic. 2, 48-51.

Perglová, I., Pergl, J., Skálová, H., Moravcová, L., Jarošík, V., Pyšek, P., 2009. Differences in germination and seedling establishment of alien and native Impatiens species. Preslia

Perrins, J., Fitter, A., Williamson, M., 1993. Population biology and rates of invasion of three introduced Impatiens species in the British Isles. J. Biogeogr. 20, 33-44.

1634 Pihl, A., 1884. Om balsaminerna. Sven. Trädgårdsföreningens Årsskrift 161-164.

1635 Power, G., Sánchez Vilas, J., 2020. Competition between the invasive Impatiens glandulifera and UK native species: the role of soil conditioning and pre-existing resident communities. Biol. Invasions 22, 1527-1537. https://doi.org/10.1007/s10530-020$02202-\mathrm{y}$

Pratt, C.F., Shaw, R.H., Tanner, R.A., Vos, J.G.M., 2013. Biological control of invasive non- 

native weeds: An opportunity not to be ignored. Entomol. Ber. 73, 144-154.

1641 Provan, J., Love, H.M., Maggs, C.A., 2007. Development of microsatellites for the invasive 1642 riparian plant Impatiens glandulifera (Himalayan balsam) using intersimple sequence 1643 repeat cloning: Primer note. Mol. Ecol. Notes 7, 451-453.

$1644 \quad$ https://doi.org/10.1111/j.1471-8286.2006.01614.x

1645 Prowse, A., 2001. Ecological effects of the invasion of native plant communities by the alien 1646 Himalayan Balsam (Impatiens Gladulifera Royle). University of Manchester.

1647 Pyšek, P., Prach, K., 1995. Invasion dynamics of Impatiens glandulifera - A century of 1648 spreading reconstructed. Biol. Conserv. 74, 41-48. https://doi.org/10.1016/0006$1649 \quad 3207(95) 00013-\mathrm{T}$

1650 Pyšek, P., Prach, K., 1993. Plant invasions and the role of riparian habitats: a comparison of four species alien to central Europe, in: Ecosystem Management. Springer, pp. 254-263.

Rotherham, I.D., 2001. Himalayan Balsam-the human touch. Exot. Invasive Species-should we be concerned? Institute of Ecology and Environmental Management Conference,

Ruckli, R., Hesse, K., Glauser, G., Rusterholz, H.P., Baur, B., 2014a. Inhibitory potential of naphthoquinones leached from leaves and exuded from roots of the invasive plant Impatiens glandulifera. J. Chem. Ecol. 40, 371-378. https://doi.org/10.1007/s10886-

1659 Ruckli, R., Rusterholz, H.P., Baur, B., 2014b. Invasion of an annual exotic plant into

Ruckli, R., Rusterholz, H.P., Baur, B., 2013. Invasion of Impatiens glandulifera affects terrestrial gastropods by altering microclimate. Acta Oecologica 47, 16-23. 

https://doi.org/10.1016/j.actao.2012.10.011

Rusterholz, H., Wirz, D., Baur, B., 2012. Garden waste deposits as a source for non-native plants in mixed deciduous forests. Appl. Veg. Sci. 15, 329-337.

Rusterholz, H.P., Salamon, J.A., Ruckli, R., Baur, B., 2014. Effects of the annual invasive plant Impatiens glandulifera on the Collembola and Acari communities in a deciduous

Scharfy, D., Funk, A., Olde Venterink, H., Güsewell, S., 2011. Invasive forbs differ 
invasive Impatiens species during a five-year field experiment under various environmental conditions. NeoBiota 50, 75-95. https://doi.org/10.3897/neobiota.50.34827

Skálová, H., Moravcová, L., Pyšek, P., 2011. Germination dynamics and seedling frost

Skálová, H., Pyšek, P., 2009. Germination and establishment of invasive and native Impatiens species in species-specific microsites. Neobiota 8, 101-109.

Smith, O.P., 2013. Allelopathic potential of the invasive alien Himalayan Balsam (Impatiens glandulifera Royle). University of Plymouth.

1701

1702

1703

1704

1705

1706

1707

1708

1709

1710

1711

1712

1713 Štajerová, K., Šmilauerová, M., Šmilauer, P., 2009. Arbuscular mycorrhizal symbiosis of 
1715 Starý, P., Rakhshani, E., Tomanović, Ž., Kavallieratos, N.G., Petrović, A., Žikić, V., 1716 Havelka, J., 2014. Aphid-parasitoid associations on the Impatiens plants in Central 1717 Europe (Hemiptera, Aphididae; Hymenoptera, Braconidae, Aphidiinae). J. Entomol. $1718 \quad$ Res. Soc. 16, 33-43.

1719 Starý, P., Tkalcu, B., 1998. Bumble-bees (Hym., Bombidae) associated with the expansive 1720 touch-me-not, Impatiens glandulifera in wetland biocorridors. Anzeiger für

Stefanowicz, A.M., Stanek, M., Majewska, M.L., Nobis, M., Zubek, S., 2019. Invasive plant species identity affects soil microbial communities in a mesocosm experiment. Appl.

Stevens, P.F., 2001. Angiosperm Phylogeny Website. Version 14, July 2017 [and more or less continuously updated since] [WWW Document]. URL

$$
\text { Soil Ecol. 136, 168-177. https://doi.org/10.1016/j.apsoil.2019.01.004 }
$$
http://www.mobot.org/MOBOT/research/APweb/

Strayer, D.L., D’Antonio, C.M., Essl, F., Fowler, M.S., Geist, J., Hilt, S., Jarić, I., Jöhnk, K., Jones, C.G., Lambin, X., Latzka, A.W., Pergl, J., Pyšek, P., Robertson, P., von Schmalensee, M., Stefansson, R.A., Wright, J., Jeschke, J.M., 2017. Boom-bust dynamics in biological invasions: towards an improved application of the concept. Ecol. Lett. 20, 1337-1350. https://doi.org/10.1111/ele.12822

Strømme, C.B., 2012. Quantity and quality of light affect growth and reproduction of the invasive annual plant Impatiens glandulifera. Norwegian University of Life Sciences.

Szewczyk, K., Bonikowski, R., Maciąg-Krajewska, A., Abramek, J., Bogucka-Kocka, A., 2018. Lipophilic components and evaluation of the cytotoxic and antioxidant activities of Impatiens glandulifera Royle and Impatiens noli-tangere L. (Balsaminaceae). Grasas y Aceites 69, e270. https://doi.org/10.3989/gya.0234181

Szewczyk, K., Sezai Cicek, S., Zidorn, C., Granica, S., 2019. Phenolic constituents of the 
aerial parts of Impatiens glandulifera Royle (Balsaminaceae) and their antioxidant activities. Nat. Prod. Res. 33, 2851-2855.

Szewczyk, K., Zidorn, C., Biernasiuk, A., Komsta, Ł., Granica, S., 2016. Polyphenols from Impatiens (Balsaminaceae) and their antioxidant and antimicrobial activities. Ind. Crops Prod. 86, 262-272. https://doi.org/10.1016/j.indcrop.2016.03.053

Tabak, N.M., Von Wettberg, E., 2008. Native and introduced jewelweeds of the Northeast. Northeast. Nat. 15, 159-176. https://doi.org/10.1656/10926194(2008)15[159:NAIJOT]2.0.CO;2

Tanner, R., Djeddour, D., 2010. Collaborative research between UK and India paves the way

Tanner, R., Ellison, C., Shaw, R., Evans, H., Gange, A., 2008. Losing patience with Impatiens: Are natural enemies the solution? Outlooks Pest Manag. 19, 86-91.

Tanner, R.A., 2017. Information on measures and related costs in relation to species included on the Union list: Impatiens glandulifera. Technical note prepared by IUCN for the

Tanner, R.A., 2008. A review on the potential for the biological control of the invasive weed, Impatiens glandulifera in Europe, in: Plant Invasions: Human Perception, Ecological Impacts and Management. pp. 343-354.

1763 Tanner, R.A., 2007. Biocontrol can touch touch-me-not. Biocontrol News Information, CABI $28,15 \mathrm{~N}-16 \mathrm{~N}$. 
1765 Tanner, R.A., Ellison, C.A., Seier, M.K., Kovács, G.M., Kassai-Jáger, E., Berecky, Z., Varia,

1766 S., Djeddour, D., Singh, M.C., Csiszár, Á., Csontos, P., Kiss, L., Evans, H.C., 2014a.

1767 Puccinia komarovii var. glanduliferae var. nov.: a fungal agent for the biological control

1768 of Himalayan balsam (Impatiens glandulifera). Eur. J. Plant Pathol. 141, 247-266.

1769 https://doi.org/10.1007/s10658-014-0539-x

1770 Tanner, R.A., Gange, A.C., 2020. Himalayan balsam, Impatiens glandulifera: its ecology, 1771 invasion and management. Weed Res. 60, 4-7. https://doi.org/10.1111/wre.12401

1772 Tanner, R.A., Gange, A.C., 2013. The impact of two non-native plant species on native flora 1773 performance: potential implications for habitat restoration. Plant Ecol. 214, 423-432.

$1774 \quad$ https://doi.org/10.1007/s11258-013-0179-9

1775 Tanner, R.A., Jin, L., Shaw, R., Murphy, S.T., Gange, A.C., 2014b. An ecological 1776 comparison of Impatiens glandulifera Royle in the native and introduced range. Plant Ecol. 215, 833-843. https://doi.org/10.1007/s11258-014-0335-x

Tanner, R.A., Pollard, K.M., Varia, S., Evans, H.C., Ellison, C.A., 2015. First release of a fungal classical biocontrol agent against an invasive alien weed in Europe: Biology of the rust, Puccinia komarovii var. glanduliferae. Plant Pathol. 64, 1130-1139.

Tanner, R.A., Varia, S., Eschen, R., Wood, S., Murphy, S.T., Gange, A.C., 2013. Impacts of an invasive non-native annual weed, Impatiens glandulifera, on above- and belowground invertebrate communities in the United Kingdom. PLoS One 8, e67271.

The Plant List, 2013. Version 1.1. Published on the Internet; http://www.theplantlist.org/ [WWW Document]. 

species. Biol. Invasions 14, 355-365. https://doi.org/10.1007/s10530-011-0067-y

1791

1792

1793

1794

1795

1796

1797

1798

1799

1800

1801

1802

1803

1804

1805

1806

1807

1808

1809

1810

1811

1812

1813

1814

Tickner, D.P., Angold, P.G., Gurnell, A.M., Mountford, J.O., Sparks, T., 2001. Hydrology as an influence on invasion: Experimental investigations into competition between the alien Impatiens glandulifera and the native Urtica dioica in the UK, in: Brundu, G., Brock, J., Camarda, L., Child, L., Wade, M. (Eds.), Plant Invasions: Species Ecology and Ecosystem Management. Blackhuys Publishers, Leiden, The Netherlands, pp. 159-168.

Titze, A., 2000. The efficiency of insect pollination of the neophyte Impatiens glandulifera (Balsaminaceae). Nord. J. Bot. 20, 33-42. https://doi.org/10.1111/j.17561051.2000.tb00729.x

Tokarska-Guzik, B., Dajdok, Z., Zając, M., Zając, A., Urbisz, A., Danielewicz, W., Hołdyński, C., 2012. Rośliny obcego pochodzenia w Polsce ze szczególnym uwzględnieniem gatunków inwazyjnych. Gen. Dyrekcja Ochr. Środowiska, Warszawa 197.

Tř́iska, J., Vrchotová, N., Sýkora, J., Moos, M., 2013. Separation and identification of 1,2,4trihydroxynaphthalene-1-O-glucoside in Impatiens glandulifera Royle. Molecules 18, 8429-8439. https://doi.org/10.3390/molecules 18078429

Tyler, T., Herbertsson, L., Olofsson, J., Olsson, P.A., 2021. Ecological indicator and traits values for Swedish vascular plants. Ecol. Indic. 120, 106923. https://doi.org/10.1016/j.ecolind.2020.106923

Ugoletti, P., Reidy, D., Jones, M.B., Stout, J.C., 2013. Do native bees have the potential to promote interspecific pollination in introduced Impatiens species? J. Pollinat. Ecol. 11, 1-8. https://doi.org/10.26786/1920-7603(2013)1

Ugoletti, P., Stout, J.C., Jones, M.B., 2011. Ecophysiological traits of invasive and noninvasive introduced Impatiens species. Biol. Environ. Proc. R. Irish Acad. 111B, 143156. https://doi.org/10.3318/BIOE.2011.12 
1815 Van Cleemput, E., Helsen, K., Feilhauer, H., Honnay, O., Somers, B., 2020a. Spectrally

1816 defined plant functional types adequately capture multidimensional trait variation in

1817 herbaceous communities. Ecol. Indic. in press.

1818 Van Cleemput, E., Van Meerbeek, K., Helsen, K., Honnay, O., Somers, B., 2020b. Remotely

1819 sensed plant traits can provide insights into ecosystem impacts of plant invasions: a case

1820 study covering two functionally different invaders. Biol. Invasions early view.

$1821 \quad$ https://doi.org/https://doi.org/10.1007/s10530-020-02338-x

1822 Van Meerbeek, K., Appels, L., Dewil, R., Calmeyn, A., Lemmens, P., Muys, B., Hermy, M.,

1823 2015. Biomass of invasive plant species as a potential feedstock for bioenergy

1824 production. Biofuels, Bioprod. Biorefining 9, 273-282. https://doi.org/10.1002/bbb.1539

1825 Vanderplanck, M., Roger, N., Moerman, R., Ghisbain, G., Gérard, M., Popowski, D.,

1826 Granica, S., Fournier, D., Meeus, I., Piot, N., Smagghe, G., Terrana, L., Michez, D.,

1827 2019. Bumble bee parasite prevalence but not genetic diversity impacted by the invasive

1828 plant Impatiens glandulifera. Ecosphere 10, e02804. https://doi.org/10.1002/ecs2.2804

1829 Vangansbeke, P., Máliš, F., Hédl, R., Chudomelová, M., Vild, O., Wulf, M., Jahn, U., Welk,

1830 E., Rodríguez-Sánchez, F., De Frenne, P., 2020. ClimPlant: climatic niches of European 1831 forest plants. Glob. Ecol. Biogeogr. under review.

1832 Varia, S., Pollard, K., Ellison, C., 2016. Implementing a novel weed management approach

1833 for Himalayan balsam: Progress on biological control in the UK. Outlooks Pest Manag.

1834 27, 198-203. https://doi.org/10.1564/v27_oct_02

1835 Vervoort, A., Cawoy, V., Jacquemart, A.L., 2011. Comparative reproductive biology in co-

1836 occurring invasive and native Impatiens species. Int. J. Plant Sci. 172, 366-377.

1837 https://doi.org/10.1086/658152

1838 Vieira, M.N., Winterhalter, P., Jerz, G., 2016. Flavonoids from the flowers of Impatiens

1839 glandulifera Royle isolated by high performance countercurrent chromatography. 
1841 Vinogradova, Y.K., Aistova, E. V, Antonova, L.A., Chernyagina, O.A., Chubar, E.A., Nikolin, E.G., Prokopenko, S. V, Rubtsova, T.A., Sheiko, V. V, Kudryavtseva, E.P., Krestov, P. V, 2020. Invasive plants in flora of the Russian Far East : the checklist and

Vrchotová, N., Šerá, B., Krejčová, J., 2011. Allelopathic activity of extracts from Impatiens species. Plant, Soil Environ. 57, 57-60. https://doi.org/10.17221/156/2010-pse

Wadsworth, R.A., Collingham, Y.C., Willis, S.G., Huntley, B., Hulme, P.E., 2000. Simulating the spread and management of alien riparian weeds: Are they out of control? comments. Bot. Pacifica. A J. plant Sci. Conserv. 9, 1-27. https://doi.org/10.17581/bp.2020.09107 J. Appl. Ecol. 37, 28-38. https://doi.org/10.1046/j.1365-2664.2000.00551.x

Walker, N.F., Hulme, P.E., Hoelzel, A.R., 2009. Population genetics of an invasive riparian species, Impatiens glandulifera. Plant Ecol. 203, 243-252. https://doi.org/10.1007/s11258-008-9540-9

Willis, S.G., Hulme, P.E., 2004. Environmental severity and variation in the reproductive traits of Impatiens glandulifera. Funct. Ecol. 18, 887-898. https://doi.org/10.1111/j.0269-8463.2004.00907.x

Willis, S.G., Hulme, P.E., 2002. Does temperature limit the invasion of Impatiens glandulifera and Heracleum mantegazzianum in the UK? Funct. Ecol. 16, 530-539. https://doi.org/10.1046/j.1365-2435.2002.00653.x

Wright, I.J., Reich, P.B., Westoby, M., Ackerly, D.D., Baruch, Z., Bongers, F., CavenderBares, J., Chapin, T., Cornelissen, J.H.C., Diemer, M., Flexas, J., Garnier, E., Groom, P.K., Gulias, J., Hikosaka, K., Lamont, B.B., Lee, T., Lee, W., Lusk, C., Midgley, J.J., Navas, M.-L., Niinemets, Ü., Oleksyn, J., Osada, N., Poorter, H., Poot, P., Prior, L., 

Pyankov, V.I., Roumet, C., Thomas, S.C., Tjoelker, M.G., Veneklaas, E.J., Villar, R., 2004. The worldwide leaf economics spectrum. Nature 428, 821-827. https://doi.org/10.1038/nature02403

Zając, A., Tokarska-Guzik, B., Zając, M., 2011. The role of rivers and streams in the migration of alien plants into the Polish Carpathians. Biodivers. Res. Conserv. 23, 4356. https://doi.org/10.2478/v10119-011-0012-z

Zając, A., Zając, M., 2015. Rozmieszczenie kenofitów w Karpatach polskich i na ich przedpolu. Instytut Botaniki Uniwersytetu Jagiellońskiego, Kraków.

Zellweger, F., de Frenne, P., Lenoir, J., Vangansbeke, P., Verheyen, K., BernhardtRömermann, M., Baeten, L., Hédl, R., Berki, I., Brunet, J., van Calster, H., Chudomelová, M., Decocq, G., Dirnböck, T., Durak, T., Heinken, T., Jaroszewicz, B., Kopecký, M., Máliš, F., Macek, M., Malicki, M., Naaf, T., Nagel, T.A., Ortmann-Ajkai, A., Petř́ḱ, P., Pielech, R., Reczynska, K., Schmidt, W., Standovár, T., Swierkosz, K., Teleki, B., Vild, O., Wulf, M., Coomes, D., 2020. Forest microclimate dynamics drive plant responses to warming. Science (80-. ). 368, 772-775. https://doi.org/10.1126/science.aba6880

Zybartaite, L., Zukauskiene, J., Jodinskiene, M., Janssens, S.B., Paulauskas, A., Kupcinskiene, E., 2011. RAPD analysis of genetic diversity among Lithuanian 
1886 Table 1. Overview of Impatiens glandulifera's functional traits and leaf nutrient concentrations

1887 in several European regions (mean and standard error). Data from Van Cleemput et al. (2020a),

1888 Helsen et al. (2017) and Helsen et al. (2018b) is based on 6, 5 and 10 populations, respectively.

1889 Data of Van Cleemput et al. (2020a) is from unshaded populations across north Belgium. Data 1890 of Helsen et al. (2018b, 2017) is from semi-shaded plots near Amiens (France), Ghent 1891 (Belgium), Bremen (Germany), Landskrona (south Sweden), Stockholm (central Sweden) and 1892 Trondheim (Norway). SLA = specific leaf area, LDMC = leaf dry matter content, SSD = stem 1893 specific density, $\mathrm{Chl}=$ chlorophyll concentration, Carot $=$ carotenoid concentration.

\begin{tabular}{|c|c|c|c|c|c|c|c|}
\hline \multirow{2}{*}{$\begin{array}{l}\text { Source } \\
\text { Country }\end{array}$} & \multirow{2}{*}{$\begin{array}{l}\text { Van Cleemput et } \\
\text { al. }(2020 a)(n=6) \\
\text { BE }\end{array}$} & \multicolumn{6}{|c|}{ Helsen et al. $(2017,2018 b)(n=10$, except $*: n=5)$} \\
\hline & & FR* & $\mathrm{BE}$ & $\mathrm{DE}$ & $\begin{array}{l}\text { south } \\
\text { SE }\end{array}$ & $\begin{array}{l}\text { central } \\
\text { SE }\end{array}$ & NO \\
\hline Plant height $(\mathrm{cm})$ & $176.7 \pm 11$ & $\begin{array}{l}164.0 \pm \\
10.1\end{array}$ & $\begin{array}{l}127.8 \pm \\
9.2\end{array}$ & $\begin{array}{l}159.8 \pm \\
7.5\end{array}$ & $\begin{array}{l}153.6 \pm \\
5.1\end{array}$ & $\begin{array}{l}155.8 \pm \\
7.4\end{array}$ & $\begin{array}{l}137.2 \pm \\
4.7\end{array}$ \\
\hline Latitude $\left({ }^{\circ} \mathrm{N}\right) /$ & $50.8 /$ & $49.9 /$ & $51.1 /$ & $53.1 /$ & $55.7 /$ & $59.3 /$ & $63.4 /$ \\
\hline longitude $\left({ }^{\circ} \mathrm{E}\right)$ & 4.8 & 2.3 & 3.7 & 8.8 & 13.2 & 18.1 & 10.4 \\
\hline Seed mass $(\mathrm{mg})^{*}$ & & $\begin{array}{l}1.96 \pm \\
0.24\end{array}$ & $\begin{array}{l}2.13 \pm \\
0.46\end{array}$ & $\begin{array}{l}1.64 \pm \\
0.07\end{array}$ & $\begin{array}{l}1.93 \pm \\
0.17\end{array}$ & $\begin{array}{l}2.04 \pm \\
0.15\end{array}$ & $\begin{array}{l}2.17 \pm \\
0.20\end{array}$ \\
\hline leaf area $\left(\mathrm{mm}^{2}\right)$ & $4672 \pm 398$ & & $\begin{array}{l}6978 \pm \\
495\end{array}$ & $\begin{array}{l}6063 \pm \\
450\end{array}$ & $\begin{array}{l}6162 \pm \\
350\end{array}$ & $\begin{array}{l}5315 \pm \\
566\end{array}$ & $\begin{array}{l}4003 \pm \\
579\end{array}$ \\
\hline $\operatorname{SLA}\left(\mathrm{mm}^{2} \mathrm{mg}^{-1}\right)$ & $22.2 \pm 1.6$ & & $\begin{array}{l}40.5 \pm \\
2.5\end{array}$ & & $\begin{array}{l}44.8 \pm \\
4.2\end{array}$ & $\begin{array}{l}35.0 \pm \\
2.0\end{array}$ & $\begin{array}{l}34.3 \pm \\
1.6\end{array}$ \\
\hline $\mathrm{LDMC}\left(\mathrm{mg} \mathrm{g}^{-1}\right)$ & $214.1 \pm 6.6$ & & $\begin{array}{l}141 \pm \\
6.0\end{array}$ & & $\begin{array}{l}140.4 \pm \\
6.0\end{array}$ & $\begin{array}{l}152.6 \pm \\
3.0\end{array}$ & $\begin{array}{l}144.3 \pm \\
3.9\end{array}$ \\
\hline $\mathrm{SSD}\left(\mathrm{mg} \mathrm{mm}^{-3}\right)$ & & & $\begin{array}{l}0.065 \pm \\
0.003\end{array}$ & $\begin{array}{l}0.074 \pm \\
0.005\end{array}$ & $\begin{array}{l}0.081 \pm \\
0.004\end{array}$ & $\begin{array}{l}0.085 \pm \\
0.006\end{array}$ & $\begin{array}{l}0.080 \pm \\
0.003\end{array}$ \\
\hline $\mathrm{Chl}\left(\mathrm{mg} \mathrm{g}^{-1}\right)$ & $5.86 \pm 1.63$ & & & & & & \\
\hline $\mathrm{Chl} \mathrm{a} / \mathrm{b}$ ratio & $2.58 \pm 0.04$ & & & & & & \\
\hline Carot $\left(\mathrm{mg} \mathrm{g}^{-1}\right)$ & $1.18 \pm 0.46$ & & & & & & \\
\hline $\mathrm{C} / \mathrm{N}$ ratio & $14.53 \pm 1.44$ & & & & & & \\
\hline Leaf $\mathrm{N}\left(\mathrm{mg} \mathrm{g}^{-1}\right)$ & $30.11 \pm 2.71$ & & & & & & \\
\hline Leaf $\mathrm{P}\left(\mathrm{mg} \mathrm{g}^{-1}\right)$ & $2.95 \pm 0.21$ & & & & & & \\
\hline Leaf $\mathrm{K}\left(\mathrm{mg} \mathrm{g}^{-1}\right)$ & $10.61 \pm 0.82$ & & & & & & \\
\hline Leaf $\mathrm{Ca}\left(\mathrm{mg} \mathrm{g}^{-1}\right)$ & $22.98 \pm 2.68$ & & & & & & \\
\hline Leaf $\mathrm{Mg}\left(\mathrm{mg} \mathrm{g}^{-1}\right)$ & $3.09 \pm 0.32$ & & & & & & \\
\hline Leaf $S\left(\mathrm{mg} \mathrm{g}^{-1}\right)$ & $2.22 \pm 0.19$ & & & & & & \\
\hline Leaf $\mathrm{Na}\left(\mathrm{mg} \mathrm{g}^{-1}\right)$ & $0.13 \pm 0.03$ & & & & & & \\
\hline Leaf $\mathrm{Zn}\left(\mu \mathrm{g} \mathrm{g}^{-1}\right)$ & $96.6 \pm 24.1$ & & & & & & \\
\hline Leaf $M n\left(\mu g^{-1}\right)$ & $94.8 \pm 32.2$ & & & & & & \\
\hline
\end{tabular}


1895 Table 2. Biotic conditions: the most frequent co-occurring species of Impatiens glandulifera

1896 in several European regions. Frequency (\% of plots present) is given for each species. Data

1897 from Helsen et al. (2018b) is based on 10 vegetation plots near Ghent (Belgium), Bremen

1898 (Germany), Landskrona (south Sweden), Stockholm (central Sweden) and Trondheim

1899 (Norway). Data from Diekmann et al. (2016) based on 50 invaded sites from different habitats

1900 near Bremen.

\begin{tabular}{|c|c|c|c|c|c|c|}
\hline \multirow{2}{*}{$\begin{array}{l}\text { Source } \\
\text { Country }\end{array}$} & \multicolumn{5}{|c|}{$\begin{array}{l}\text { Helsen et al. }(2018 b) \\
(n=10 \text { for each country })\end{array}$} & \multirow{2}{*}{$\begin{array}{c}\text { Diekmann et al. } \\
(2016)(n=50) \\
\text { DE }\end{array}$} \\
\hline & $\mathrm{BE}$ & $\mathrm{DE}$ & $\begin{array}{l}\text { south } \\
\text { SE }\end{array}$ & $\begin{array}{l}\text { central } \\
\text { SE }\end{array}$ & NO & \\
\hline Aegopodium podagraria & 40 & 10 & 70 & 20 & 30 & 24 \\
\hline Agrostis stolonifera & 10 & 10 & & 30 & 30 & \\
\hline Alliaria petiolata & & & & 10 & & 20 \\
\hline Anthriscus sylvestris & 20 & 20 & & 20 & 40 & \\
\hline Calystegia sepium & 30 & 40 & 60 & 40 & & 38 \\
\hline Cirsium arvense & 20 & & & 50 & 50 & \\
\hline Dactylis glomerata & 20 & 10 & 30 & 40 & 20 & 22 \\
\hline Elymus repens & & & & & & 12 \\
\hline Epilobium hirsutum & 20 & 20 & 30 & & & 10 \\
\hline Filipendula ulmaria & & 30 & 20 & 60 & 50 & 28 \\
\hline Galeopsis tetrahit & 10 & 20 & 10 & 20 & 30 & \\
\hline Galium aparine & 70 & 50 & 60 & 20 & & 54 \\
\hline Geum urbanum & 20 & 20 & 50 & 30 & 10 & 10 \\
\hline Glechoma hederacea & 50 & 60 & 40 & 30 & & 50 \\
\hline Heracleum sphondylium & 50 & & 10 & & & \\
\hline Holcus lanatus & 30 & 60 & 20 & & & 12 \\
\hline Humulus lupulus & & 20 & & & & 16 \\
\hline Iris pseudacorus & & & & & & 10 \\
\hline Lolium perenne & 10 & 20 & 20 & 30 & 70 & \\
\hline Lysimachia vulgaris & & & & 10 & & 16 \\
\hline Lythrum salicaria & & 10 & & 10 & & 12 \\
\hline Phalaris arundinacea & 30 & & 20 & 30 & & 36 \\
\hline Phleum pratense & & 20 & & 20 & 50 & \\
\hline Phragmites australis & 20 & 30 & 20 & 20 & & 22 \\
\hline Poa trivialis & 40 & 10 & 30 & 20 & 30 & 46 \\
\hline Ranunculus repens & 20 & & 30 & 10 & 40 & 14 \\
\hline Rubus fruticosus agg. & 20 & 60 & 30 & & & 34 \\
\hline Rubus idaeus & & & 20 & 40 & 50 & 16 \\
\hline Rumex obtusifolius & 30 & 10 & 20 & 10 & 30 & \\
\hline Stachys sylvatica & 50 & & & & 30 & \\
\hline Urtica dioica & 100 & 100 & 80 & 100 & 70 & 92 \\
\hline
\end{tabular}

1901 
1902 Table 3. Abiotic conditions in plots invaded by Impatiens glandulifera. Mean values with 1903 standard error (SE), median values or minima and maxima are given.

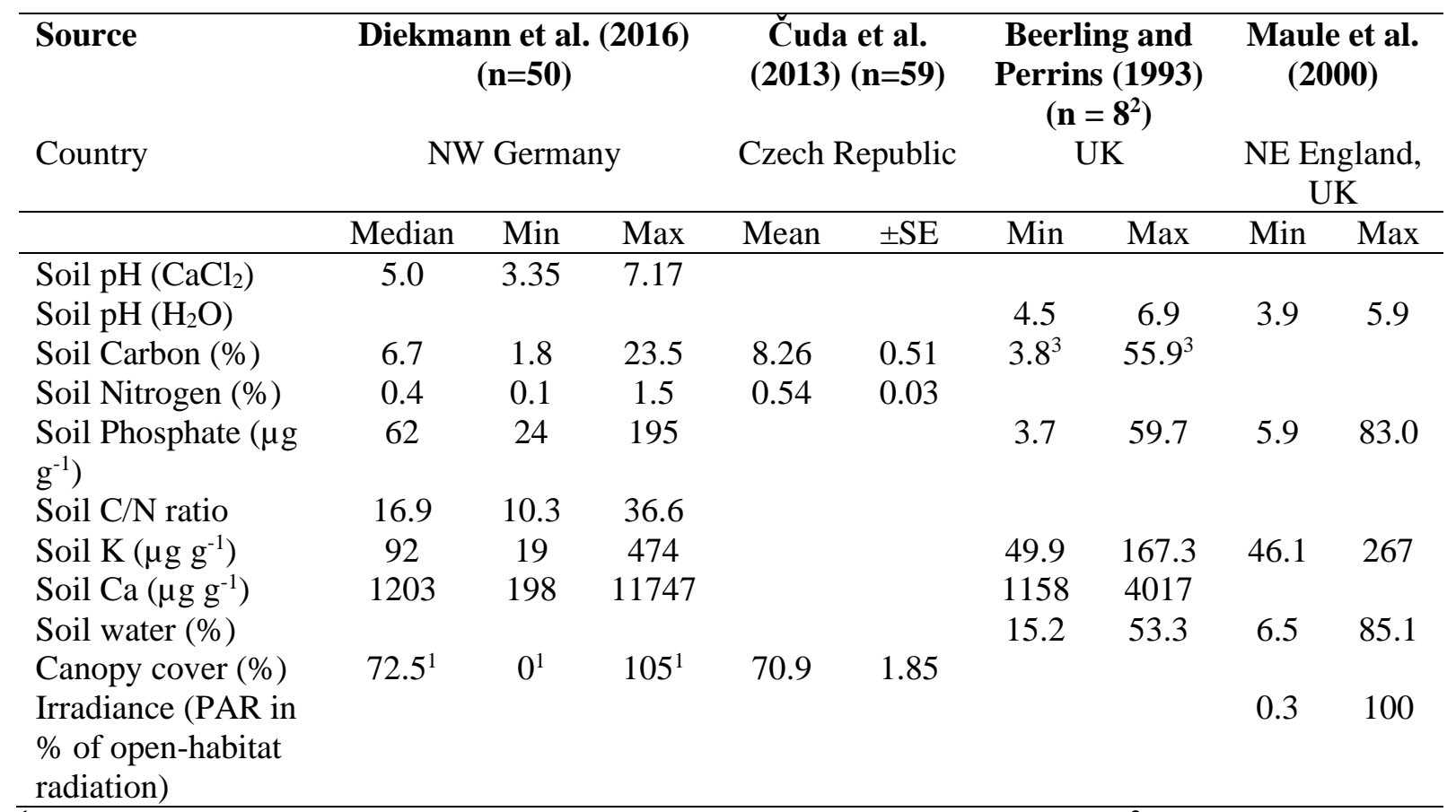

$1904{ }^{1}$ Sum of percentage cover of trees and shrubs (can be higher than $\left.100 \%\right),{ }^{2}$ Mean of five 1905 replicates, ${ }^{3}$ Organic carbon only. 
1907 Table 4. Overview of invertebrate groups observed on leaves of I. glandulifera in the UK

1908 (presence) (Beerling and Dawah, 1993) and Poland (percentage of observed total invertebrate

1909 individuals) (Najberek et al., 2020a, 2017). For Poland, only groups with putative damaging

1910 effects on I. glandulifera are included.

\begin{tabular}{|c|c|c|c|c|c|}
\hline Class & Order & Taxon & $\begin{array}{l}\text { Beerling \& } \\
\text { Dawah (1993) }\end{array}$ & $\begin{array}{l}\text { Najberek et } \\
\text { al. (2017) } \\
(\%)\end{array}$ & $\begin{array}{l}\text { Najberek et } \\
\text { al. (2020) } \\
(\%)\end{array}$ \\
\hline Arachnida & - & Acari & & 0.16 & \\
\hline \multirow[t]{24}{*}{ Insecta } & Coleoptera & - & & 0.16 & 1.02 \\
\hline & & Chrysomelidae & $x$ & & \\
\hline & & Coccinellidae & & & 0.31 \\
\hline & & Curculionidae & $x$ & & 0.86 \\
\hline & Diptera & - & & 3.20 & 1.57 \\
\hline & & Agromyzidae & $x$ & & \\
\hline & & Drosophilidae & & 2.24 & 0.16 \\
\hline & & Psychodidae & & & 0.08 \\
\hline & & Syrphidae & & 0.64 & 0.39 \\
\hline & Hemiptera & - & & 2.08 & 0.86 \\
\hline & & Aphidoidea & $\times($ Aphididae $)$ & 72.32 & 81.75 \\
\hline & & Auchenorrhyncha & & 0.96 & 0.70 \\
\hline & & Cicadellidae & $x$ & 0.16 & 0.08 \\
\hline & & Coreidae & & 0.16 & \\
\hline & & Nabiidae & $x$ & & \\
\hline & Heteroptera & Pentatomidae & & 0.48 & 0.08 \\
\hline & Hymenoptera & - & & 1.60 & 3.84 \\
\hline & & Symphyta (larvae) & & 0.16 & \\
\hline & & Vespidae & & 0.16 & \\
\hline & Lepidoptera & - (larvae) & & 0.16 & \\
\hline & & Sphingidae & $x$ & & \\
\hline & Mecoptera & - & & 0.16 & \\
\hline & Orthoptera & - & & 0.16 & \\
\hline & Psocoptera & - & & 0.16 & 0.08 \\
\hline Gastropoda & Stylommatophora & - & & 14.88 & 8.22 \\
\hline
\end{tabular}

1911 
1912 Table 5. Mineral nutrient deficiency symptoms in laboratory grown I. glandulifera. Based on

1913 Prowse (2001).

\begin{tabular}{|c|c|}
\hline Nutrient & Symptoms \\
\hline $\begin{array}{l}\text { Complete } \\
\text { nutrient } \\
\text { deficiency }\end{array}$ & $\begin{array}{l}\text { Strong growth of lateral roots, leaves dark green, glands well developed. Root hairs along } \\
\text { length of root. }\end{array}$ \\
\hline Magnesium & $\begin{array}{l}\text { Chlorosis evident in leaves, and leaves curling abaxially. Roots underdeveloped with prolific } \\
\text { root hair production. }\end{array}$ \\
\hline Calcium & Dead \\
\hline Phosphorus & $\begin{array}{l}\text { "Scorching" of leaf tips. Roots severely underdeveloped with poor lateral root growth and few } \\
\text { root hairs. }\end{array}$ \\
\hline Nitrogen & $\begin{array}{l}\text { Shoot necrotic, apex still green. Root development comparable with control. Severe chlorosis } \\
\text { in older leaves. }\end{array}$ \\
\hline Potassium & Thinning of leaves and large areas of the leaf without colour. No glandular development. \\
\hline Micronutrients & $\begin{array}{l}\text { Normal shoot growth though leaves pale green; pronounced anthocyanin colouration in stem. } \\
\text { Root development comparable with control. Glands present. }\end{array}$ \\
\hline Sulphur & $\begin{array}{l}\text { Slight chlorosis and deformation of older leaves. Roots well developed but with anthocyanin } \\
\text { colouration. Extreme proliferation of root hairs all along the root length. }\end{array}$ \\
\hline Iron & $\begin{array}{l}\text { Severe interveinal chlorosis and leaf tip "scorch" in young leaves. Roots have "stubby" } \\
\text { appearance. Glands present. }\end{array}$ \\
\hline
\end{tabular}

1914 
1915 Figures
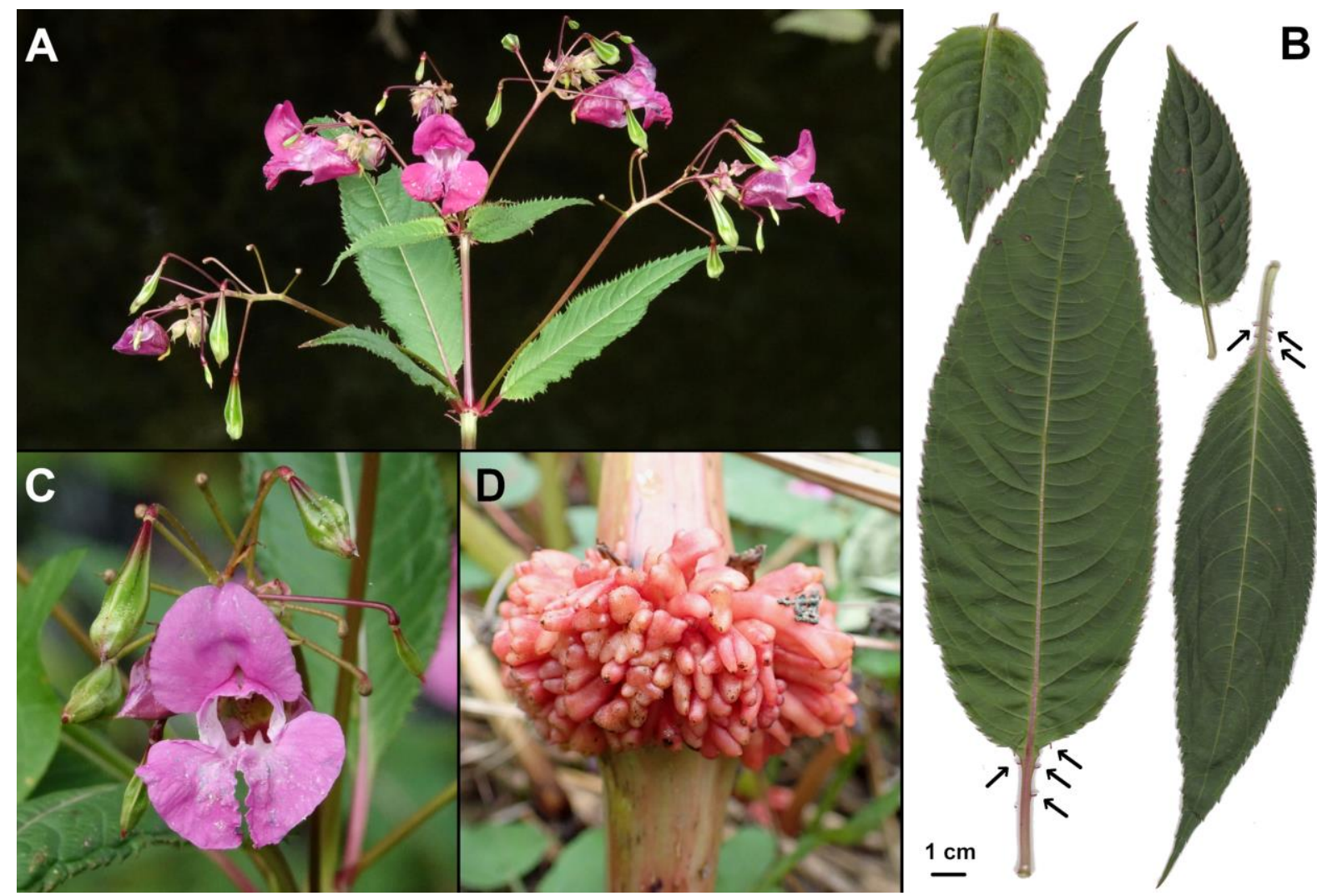

1917 Figure 1. Illustration of Impatiens glandulifera's morphology. A. Terminal inflorescence

1918 showing both flowers and capsules, B. Variation in leaf size and shape. Arrows indicate the

1919 extrafloral nectaries at the leaf base, C. Detail of flower and capsules, D. Detail of adventitious

1920 root formation on the stem after stem damage. A. \& C. (C) Sanne Govaert, B. (C) Kenny Helsen,

1921 D. CHeather A. Kelly 


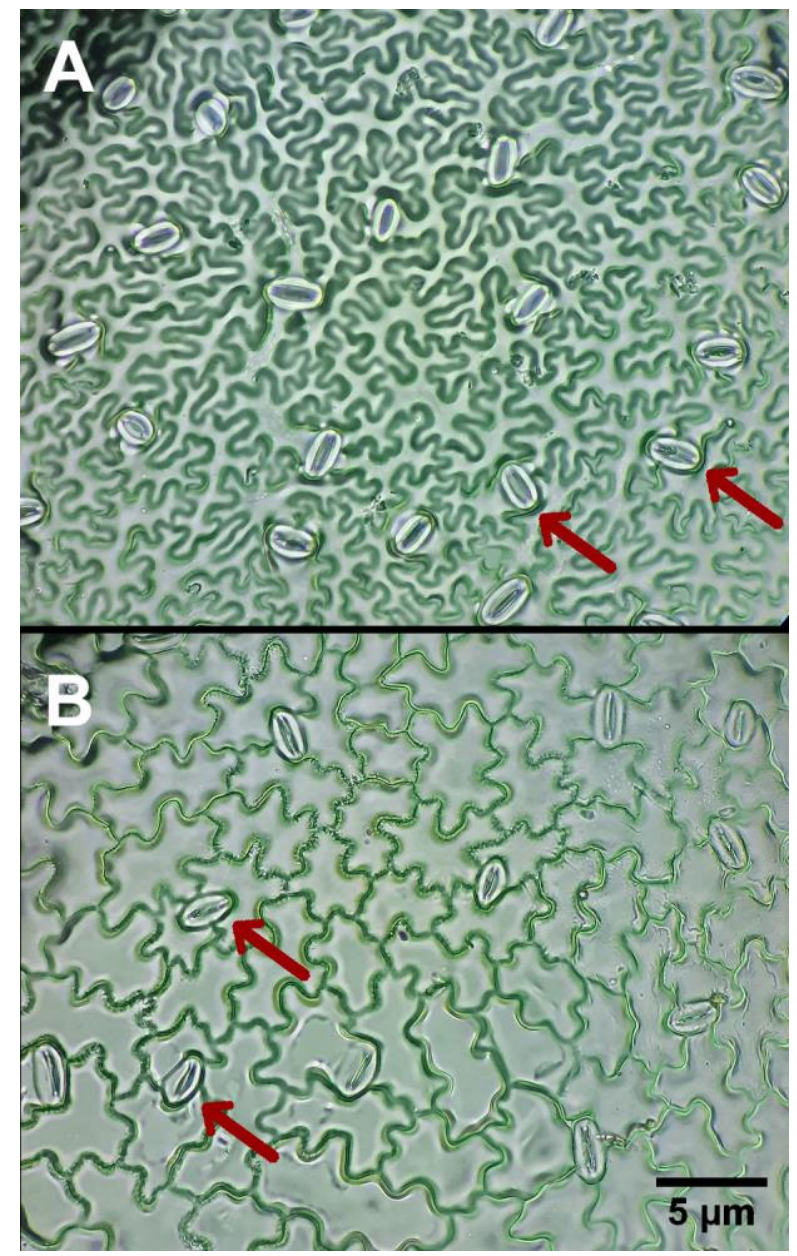

1923 Figure 2. Microscope pictures of Impatiens glandulifera's stomata (red arrows) showing

1924 higher stomatal density on A. the abaxial compared to B. the adaxial leaf side. Pictures are

1925 from a plant grown in a greenhouse in Ghent (Belgium) from seed originating from Landskrona

1926 (south Sweden, cf. Table 1). OSarah Hertecant 


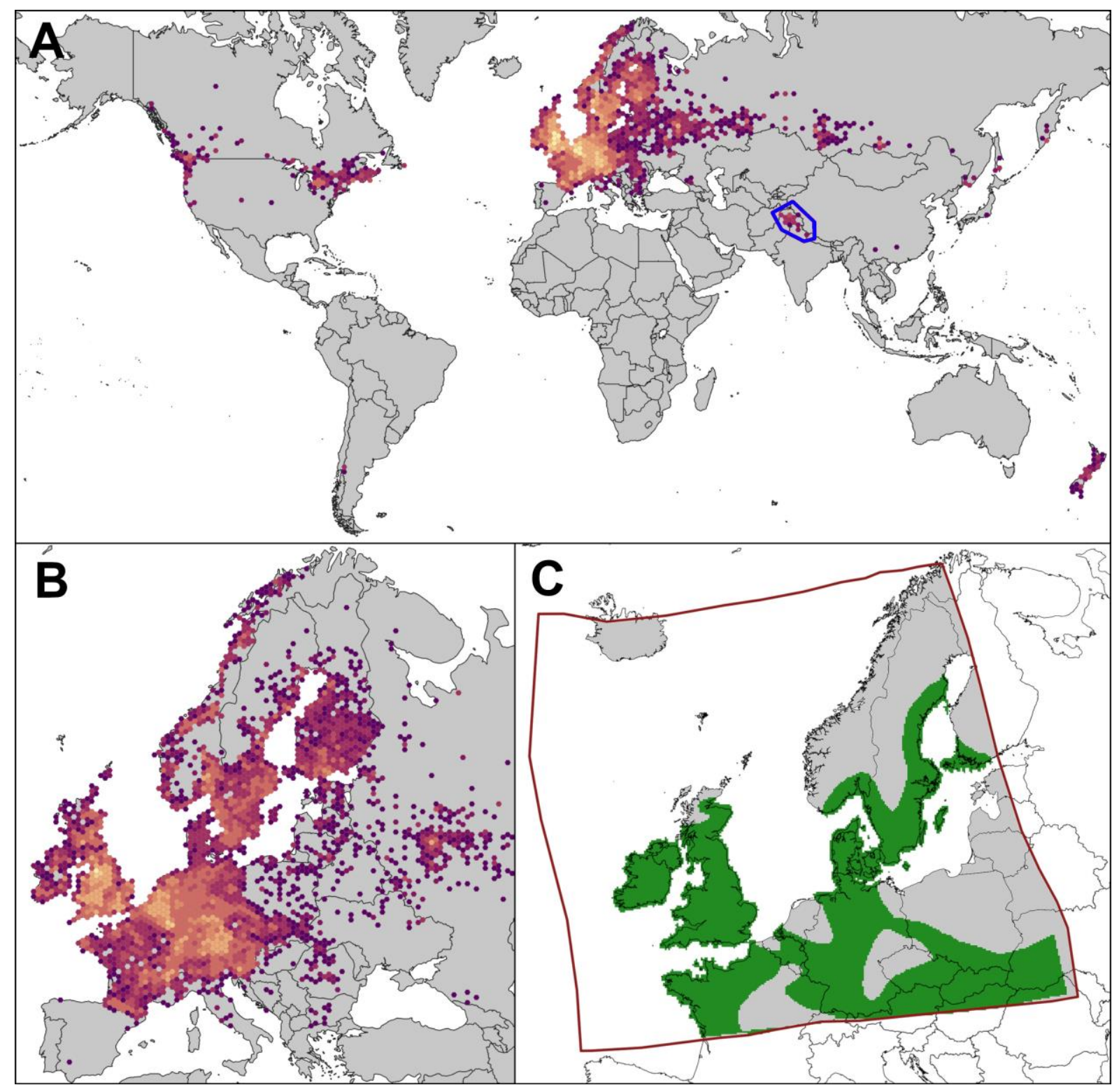

1928 Figure 3. A. Current distribution range of Impatiens glandulifera in the world, based on GBIF

1929 presence data (GBIF Secretariat, 2019), showing both the native range in the Himalayas (blue

1930 polygon) and the invaded ranges across the temperate regions of the world. B. Detail map for

1931 present distribution in Europe based on GBIF presence data. Colour warmth relates to point

1932 density. C. The expert-based distribution range of Impatiens glandulifera (green) in Europe in

19331978 (redrawn from Beerling (1993), the original source is Fitter (1978)). The baseline

1934 distribution range was only available inside the area depicted by the red polygon. The range

1935 expansion in B compared to $\mathrm{C}$ is remarkable. 


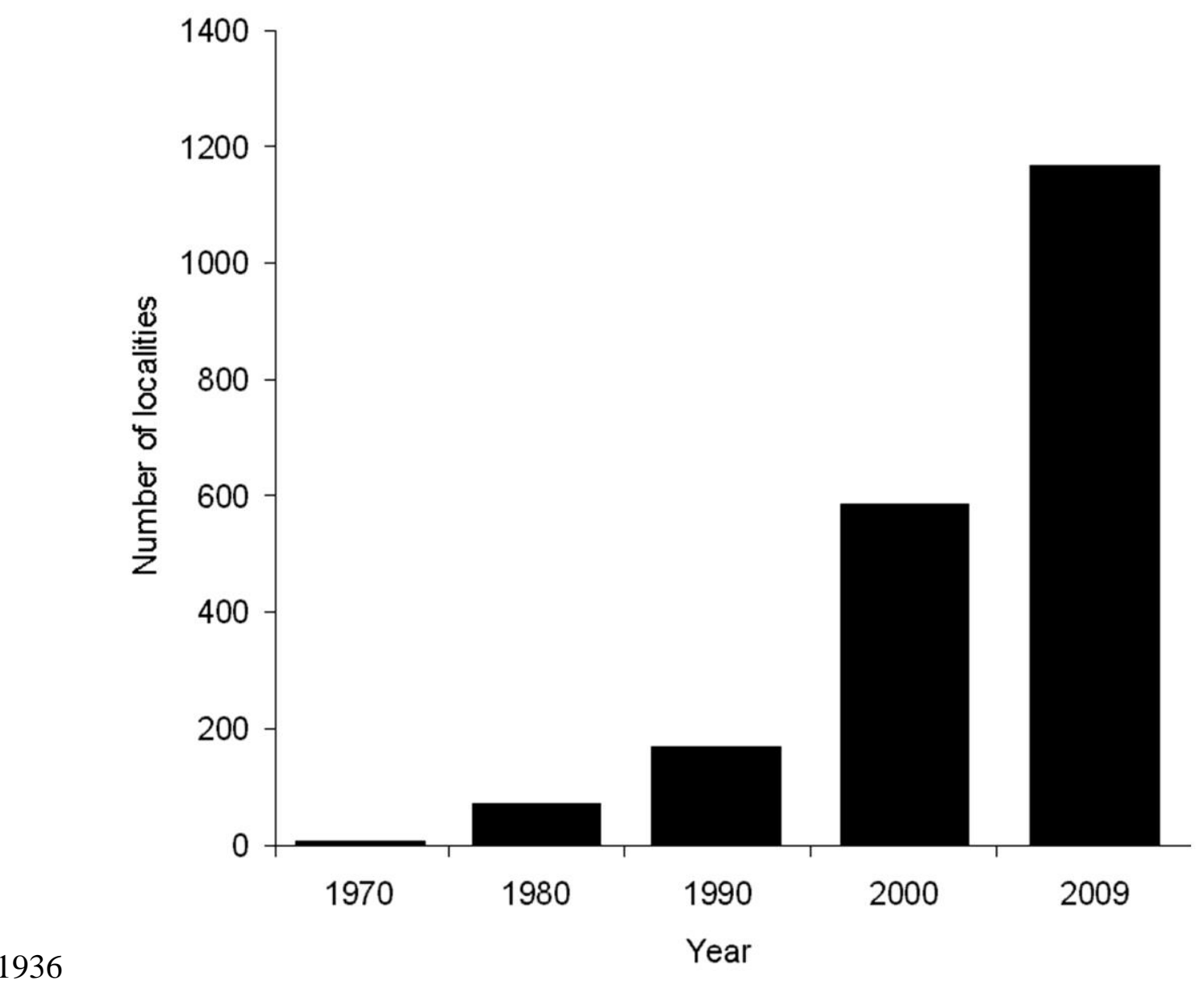

1937 Figure 4. Number of identified populations of Impatiens glandulifera in the Polish Carpathians

1938 through time, showing a rapid increase. Figure reproduced with permission, from Zając et al. 1939 (2011). 

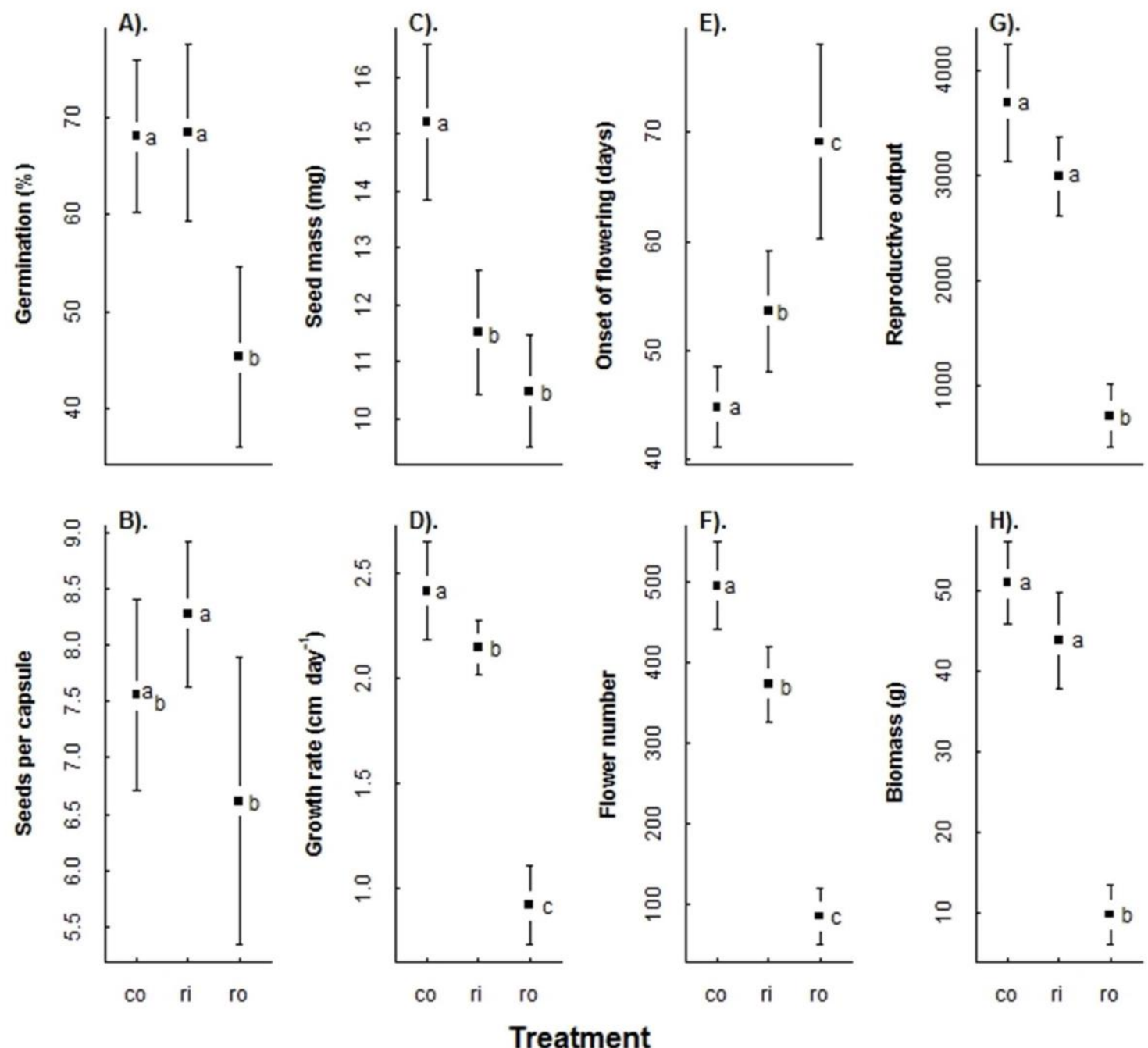

1940

1941 Figure 5. Variation in life history traits (means and 95\% CIs) of I. glandulifera grown in

1942 greenhouse conditions. $\mathrm{Co}=$ control, plants grown in an individual pot without competition

1943 of other plants, $\mathrm{ri}=$ individual plant grown in a pot with competition of riparian herbaceous-

1944 dominated vegetation and ro = plant grown in a pot with competition of graminoid-dominated

1945 roadside vegetation. Different letters represent significant differences between treatments.

1946 Onsets of flowering are measured in days after sowing. Figure reproduced from Mujuni et al.

1947 (2015). 


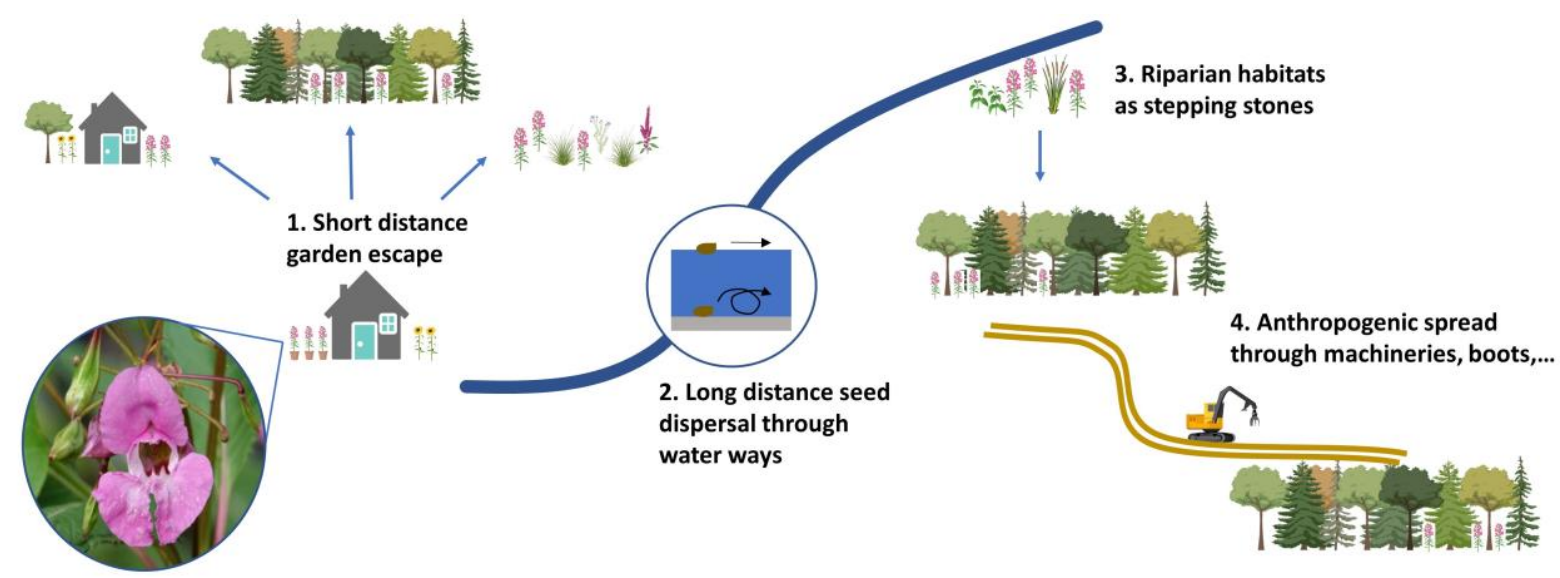

1949 Figure 6. Schematic overview of pathways of post-introduction spread of I. glandulifera. 